\title{
Hurricane Occurrence and Seasonal Activity: An Analysis of the 2017 Atlantic Hurricane Season
}

\author{
Henry Ngenyam Bang ${ }^{\circledR}$, Lee Stuart Miles, Richard Duncan Gordon \\ Disaster Management Centre, Bournemouth University, Dorset, Talbot Campus, Fern Barrow, Poole, UK \\ Email: hbang@bournenmouth.ac.uk
}

How to cite this paper: Bang, H.N., Miles, L.S. and Gordon, R.D. (2019) Hurricane Occurrence and Seasonal Activity: An Analysis of the 2017 Atlantic Hurricane Season. American Journal of Climate Change, 8, 454-481.

https://doi.org/10.4236/ajcc.2019.84025

Received: July 31, 2019

Accepted: October 21, 2019

Published: October 24, 2019

Copyright ( 2019 by author(s) and Scientific Research Publishing Inc. This work is licensed under the Creative Commons Attribution International License (CC BY 4.0).

http://creativecommons.org/licenses/by/4.0/

\begin{abstract}
This article provides a reckoning of the 2017 Atlantic Hurricane Season's place in history to ascertain how unique it was from other hurricane seasons. A research strategy involving qualitative, descriptive and analytical research approaches, including content analysis, sequential description of events and comparative analysis, were used to assess how and why the 2017 AHS season is distinct from others. Findings reveal that the 2017 AHS was extraordinary by all meteorological standards-in many ways, being hyperactive, and producing a frenetic stretch of huge, long-lived and dramatic, tropical storms including 10 hurricanes. The season was, arguably, the most expensive in history and will be remembered for the unprecedented devastation caused by the season's major hurricanes (Harvey, Irma and Maria). While the extremely active season can be attributed to anomalously high, climate change induced, hurricane friendly environmental conditions in the Atlantic basin, early forecasts did not also predict the hyperactivity of the season. This article, therefore, advances for a more strategic anticipatory and proactive approach in dealing with these severe storms, underpinned by effective mitigation of their effects. Furthermore, the article adds value to the literature examining extreme natural forces, particularly in understanding variations in the ferocity of the meteorological events associated with hurricane seasons.
\end{abstract}

\section{Keywords}

Hurricanes, Disaster, Hurricane Season, Tropical Cyclones, Seasonal Activity

\section{Introduction}

Considering that hurricanes are amongst nature's most powerful and violent storms with the potential to wreak havoc in stupendously dramatic ways, the 
fascination and curiosity to better understand these extra-ordinary forces of nature is extremely high. These storms are a common phenomenon in the Atlantic Ocean [1] and their frequency, intensity and destructive potential have been increasing in recent years [2] [3]. At the same time, the exposure of the global population to tropical cyclone (TC) hazards has been increasing as more people settle in coastal areas [4]. Indeed, an increase in the vulnerable population is reflected in a 6\% rise in TC damage between 1970 and 2015, costing about US $\$ 700$ billion. Moreover, about 470,000 people (roughly 10,000 lives per year) were killed by hurricanes between 1970 and 2010 [5].

Hurricane occurrence is not random. Particular environmental conditions are required for their formation (see Section 2.2) and countries within the vicinity of where hurricanes form is at their mercy. Historically, storms that form in the Caribbean have been a threat to all Caribbean countries while such storms, including those that form in the tropical North Atlantic and Gulf of Mexico, account for most of the hurricanes that eventually reach the South East (SE) coasts of the USA and the Greater Antilles [6] [7] [8]. Therefore, the Caribbean and the USA are amongst the most vulnerable regions in the world to severe storms. In fact, since hurricane records began in 1851, a total of 577 hurricanes have made landfall in the US up to 2016; 97 of these reaching Category 3 or above on the Saffir-Simpson scale [9]. When the 2017 Atlantic Hurricane Season (AHS) is added, the number increases to 587 hurricanes.

Of immense concern, however, is not just the number of TCs that develop in a season, but the number of major hurricanes (>category 3). The EM-DAT ${ }^{1}$ reports that 581 TCs have occurred throughout the Caribbean between 1950 and 2014, with 238 developing to hurricanes that proved disastrous to the communities affected [5]. Indeed, this number might actually be higher because only $62 \%$ of the natural hazard-induced disasters caused by TC over the last 65 years have data on the damage they caused. Systematic recording of disasters only started in 1988 [10].

Worryingly, the effects of hurricanes (destruction of physical infrastructure, capital stock and agricultural products etc.) can have a heavy toll on the economy of the affected regions. In fact, hurricanes are the costliest natural disasters in the US. For instance, since 1980, weather and climate disasters have costed the USA more than \$1.2 trillion [2] [11]. Owing to the strength of the US economy, such hazards have had less of an economic effect compared to the much smaller economies of the Caribbean countries [12] [13] [14].

These storms pose a grave threat to the development of the Caribbean region, often causing huge social, economic and environmental costs that can set back development in the affected Caribbean countries for decades [13]. Hurricanes are a major source of macroeconomic risk in the Caribbean countries with the ${ }^{1}$ The EM-DAT database records disasters throughout the world. For a disaster to be included in the database at least one of the following criteria must be met: 2) ten or more people reported killed, 2) hundred or more people reported affected, or 3) there was a declaration of a state of emergency, or a call for international assistance was made. 
potential to cause losses that wipe out an entire year of GDP. Indeed, over the past 65 years, 148 disasters occurred in the Caribbean, costing US $\$ 52$ billion, which amounts to an average of $82 \%$ GDP of the Caribbean economy. The largest disasters, particularly for the smaller islands, caused damages above $100 \%$ of GDP. For example, the damages caused by Hurricane Hugo in 1989, hitting Montserrat, costed 434\% of that island's GDP [10] (Table 1).

In recent years, the Caribbean has seen a trend of mostly weaker hurricanes; most of which stayed in the Atlantic, or if they did make landfall, did not affect densely populated areas [15]. However, this trend seems to have changed during the 2017 AHS $^{2}$.

Table 1. Damage per Caribbean Island from 1950 to 2014.

\begin{tabular}{|c|c|c|c|c|c|c|c|c|}
\hline Caribbean Islands & Disasters & Total Damages & Storm & Year & Max Wind (kts/h) & $\mathrm{H} \mathrm{Cat}^{\mathrm{a}}$ & Landfall? & $\%$ of GDP \\
\hline Anguilla & 3 & 209 & Donna & 1960 & 120 & $\mathrm{H} 4$ & Yes & $\mathrm{NA}^{\mathrm{b}}$ \\
\hline Antigua \& Barbuda & 6 & 809 & Luis & 1995 & 120 & $\mathrm{H} 4$ & Yes & 60.1 \\
\hline Bahamas & 10 & 3185 & Frances & 2004 & 120 & $\mathrm{H} 4$ & Yes & 14.1 \\
\hline Bermuda & 3 & 449 & Fabian & 2003 & 105 & $\mathrm{H} 3$ & NO & 7.2 \\
\hline Barbados & 4 & 178 & Emily & 1987 & 40 & TS & NO & 5.8 \\
\hline British Virgin Islands & 2 & 16 & Marilyn & 1995 & 95 & $\mathrm{H} 2$ & NO & 2.5 \\
\hline Cuba & 19 & 15,054 & Flora & 1963 & 104 & $\mathrm{H} 3$ & Yes & NA \\
\hline Cayman Islands & 5 & 3976 & Ivan & 2004 & 135 & $\mathrm{H} 4$ & NO & 128.9 \\
\hline Dominica & 8 & 715 & Lenry & 1999 & 120 & $\mathrm{H} 4$ & NO & 67.8 \\
\hline Dominican Republic & 14 & 6084 & Georges & 1998 & 105 & $\mathrm{H} 4$ & Yes & 9.7 \\
\hline Grenada & 3 & 1141 & Ivan & 2004 & 115 & $\mathrm{H} 3$ & NO & 148.4 \\
\hline Haiti & 14 & 2898 & Flora & 1963 & 125 & $\mathrm{H} 4$ & Yes & 74.1 \\
\hline Jamaica & 20 & 5556 & Gilbert & 1988 & 110 & $\mathrm{H} 3$ & Yes & 49.7 \\
\hline Montserrat & 2 & 404 & Hugo & 1989 & 125 & $\mathrm{H} 4$ & NO & 434.1 \\
\hline Puerto Rico & 11 & 8637 & Georges & 1998 & 95 & $\mathrm{H} 2$ & Yes & 6 \\
\hline St. Kitts \& Nevis & 4 & 1416 & Georges & 1998 & 100 & $\mathrm{H} 3$ & Yes & 220.5 \\
\hline St Lucia & 8 & 626 & Allen & 1980 & 115 & $\mathrm{H} 4$ & NO & 155.2 \\
\hline St Vincent \& the Grenadines & 6 & 113 & Allen & 1980 & 115 & $\mathrm{H} 4$ & NO & 23.3 \\
\hline Trinidad and Tobago & 4 & 188 & Flora & 1963 & 97 & $\mathrm{H} 3$ & Yes & 4.5 \\
\hline Turks \& Caicos & 2 & 513 & Ike & 2008 & 115 & $\mathrm{H} 4$ & NO & 58 \\
\hline Total & 148 & 104,336 & & & 2176 & & & 1469.9 \\
\hline Average & 7.4 & 4968.4 & & & 108.8 & & & 81.7 \\
\hline
\end{tabular}

a. Cat $=$ Hurricane Category b. GDP data not available. Related references: Adapted from the Emergency Events Database (EM-DAT) of the Centre for Research on the Epidemiology of Disasters (CRED), website of the US government's National Oceanic and Atmospheric Administration (NOAA) agency, [10].

${ }^{2}$ The Atlantic Hurricane Season is the period in a year (01 June - 30 November) when hurricanes usually form in the North Atlantic Ocean, including the Caribbean Sea and regions along the Gulf of Mexico and the Gulf Coast. 
In this article we set out to review the 2017 AHS. The primary objective is to understand how and why the 2017 AHS is different from other seasons. Therefore, the main question this research seeks to answer is: How was the 2017 AHS unique from other seasons? To this end, this article has explored the characteristics that distinguish the 2017 AHS from other seasons. In so doing, we note that despite unprecedented scientific innovations in the detection and monitoring of TCs in the 21st century, these severe storms continue to threaten human civilization.

The article adds value to the literature of extreme natural events that cause disasters. And is particularly useful for students and teachers-to provide further knowledge about the meteorological events associated with hurricane seasons (subsequently called seasons); for academics and researchers-to ensure there is justification for further research; for policy makers and disaster managers-to take concerns about natural hazard/disaster policy and resourcing more seriously.

The structure of the paper is as follows: Section 2 provides the theoretical framework that highlights key aspects of hurricanes; Section 3 describes the methods used in the study; Section 4 presents the results and discussion while Section 5 is the conclusion and recommendation.

\section{Theoretical Framework}

This section considers key aspects of hurricanes. It is underpinned by an overview of hurricane formation, distribution, measurement, seasonal activity and forecast. This sets the framework for understanding severe storms and to realize the objective of this article.

\subsection{Tropical Cyclone Nomenclature}

The term Hurricane originated from the name Hurakan ${ }^{3}$, an ancient Mayan storm god that was considered evil by the Arawakan Indians of the Caribbean islands and South America. Hurricanes are TCs that occur in the North Atlantic Ocean, North East Pacific Ocean and South Pacific Ocean. These storms are warm-core, rapid-onset and low-pressure intense tropical weather systems with sustained winds of $74 \mathrm{mph}$ (64 knots) or higher ${ }^{4}$. When the same storms occur in the North West Pacific Ocean, they are called Typhoons. When they occur in the South West Pacific and Indian Oceans, the word "Cyclone" is used [16] [17] [18] [19] [20] (Figure 1).

\subsection{Necessary Conditions for the Formation of Hurricanes}

Hurricanes are also called severe tropical storms. The phrase tropical indicates the region and environmental condition in the world where they form-warm

${ }^{3}$ Hurakan personified the tempest, rain, thunder, lightning bolt and the illumination produced by sheet lightening.

${ }^{4}$ Most definitions of TCs tend to focus on the area where they form, their mode of occurrence, their appearance and damage/loss potential. 


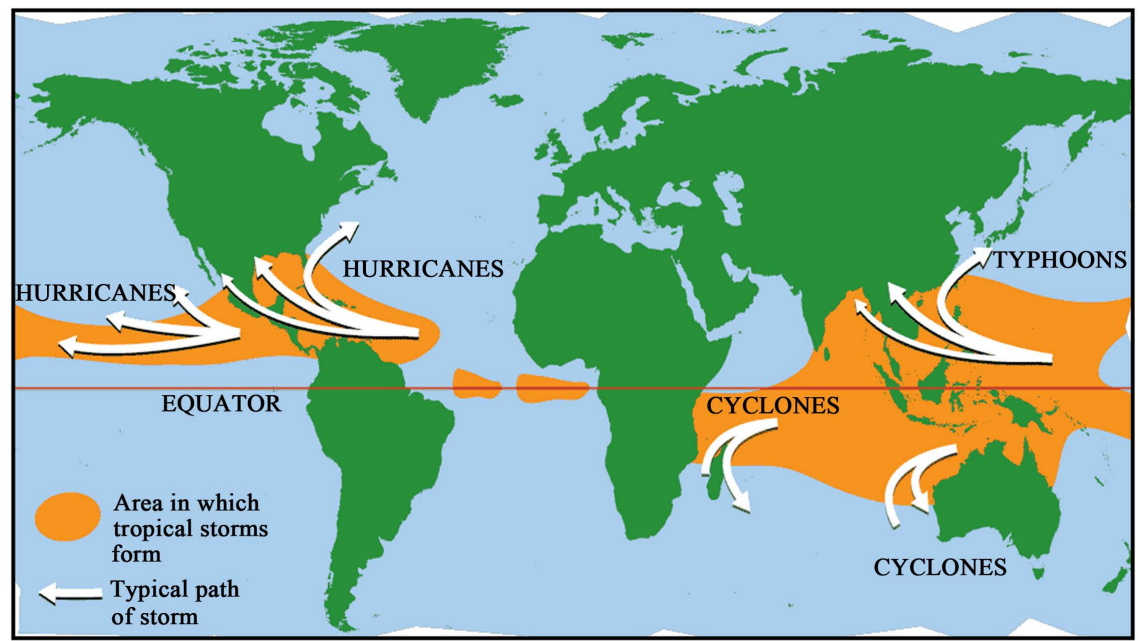

Figure 1. Areas where tropical cyclones form and typical tropical cyclone paths. Related references: Adapted from [17] [25] [26].

oceans and seas between the Tropics of Cancer and Capricorn, between longitudes 100 - 300 North and South of the equator. It should be noted, however, that not all tropical waves, disturbances, or storms develop into hurricanes. Particular environmental conditions are required for the formation of hurricanes, including: 1) Warm Tropical Ocean waters of at least $27^{\circ} \mathrm{C} / 80^{\circ} \mathrm{F}$ with a depth of about $46-50 \mathrm{~m}$-the heat in these warm waters is necessary to fuel the storm; 2) An atmosphere that cools fast enough with height such that it is potentially unstable for moist convection-the thunderstorm activity allows the heat stored in the ocean waters to be released and used for tropical cyclone development; 3) The mid-troposphere (5 $\mathrm{km}$ or 3 miles altitude), must contain enough moisture to sustain the thunderstorms-dry mid-levels are not conducive to the continuing development of thunderstorms; 4) There must be an initial disturbance of air near the surface of the ocean (within the tropics at a minimum distance of at least $500 \mathrm{~km}$ from the equator) - which causes the air to begin to spin and has low-level inflow of moist air; 5) The Coriolis force must be present ${ }^{5}$-without the Coriolis force, the low pressure of the disturbance cannot be maintained and 6) There should be a vertical wind shear ${ }^{6}$ of less than $10 \mathrm{~m} / \mathrm{s}^{7}$ (between $20-23$ $\mathrm{mph}$ ) between the surface of the ocean and the upper troposphere [17] [19]-[24].

\subsection{Worldwide Distribution of Tropical Cyclones}

TC activity varies in the different oceans. Around $12 \%$ of all TCs develop in the Atlantic Ocean, 12\% develop in the southern Pacific Ocean, 15\% develop in the eastern Pacific Ocean, 30\% develop in the western Pacific Ocean and 31\% in the

\footnotetext{
${ }^{5}$ Except in rare circumstances, hurricanes do not form within $5^{\circ}$ latitude of the equator because of the lack of Coriolis Force. The Coriolis effect is zero near the equator and increases to the north and south of the equator.

${ }^{6}$ Vertical wind shear is the rate of change of wind velocity with altitude.

${ }^{7}$ Large values of vertical wind shear disrupt the development of the tropical cyclone by removing the rising moist air too quickly.
} 
Indian Ocean both $\mathrm{N}$ and $\mathrm{S}$ of the equator (including 7\% $\mathrm{NE}$ of Australia) (Figure 1). Their movement is affected by the prevailing wind system-from East to West under the influence of trade winds [17] [25] [26] [27].

\subsection{Tropical Cyclone Seasons}

Each ocean has its own particular seasonal patterns of tropical storm activity that constitutes the seven tropical cyclone seasons as shown in Table 2. TC activity tends to peak worldwide in September, while the storms are least active in May.

\subsection{Stages in the Formation of a Tropical Cyclone/Hurricane}

There are different stages in the formation of TCs. It begins as a tropical disturbance with thunderstorm activity that might stretch about 100 miles and remain active for about 24 hours. In the Atlantic Ocean, these disturbances start as tropical waves from two dominant source regions North and South of latitude 150 over the coast of Africa and move westward often with wind speeds of less than $25 \mathrm{mph}$ [28] [29]. If the right environmental conditions exist (see Section 2.2), a tropical disturbance can develop further and begin to spin around a low-pressure center. When this happens, it is known as a tropical depression if it has wind speeds between 25 - $38 \mathrm{mph}$. Under suitable conditions, the pressure in the center of the tropical depression can drop, causing air to rush inwards. If the wind speed is strong enough to go beyond $39 \mathrm{mph}$ but less than $73 \mathrm{mph}$, the system is called a tropical storm. If favorable conditions persist, the pressure in the center of the tropical depression drops further and the winds pick up more speed. When the wind speed in this growing, swirling, vortex of air and clouds exceeds $74 \mathrm{mph}$, the system is dubbed a $T C$ or hurricane depending on where the storm developed.

A full-grown hurricane has a distinct easily identifiable structure with a spiral shape as shown on Figure 2. At the center of the spiral is a visible "eye" (empty space) where air sinks (downdraft), in an attempt to fill the empty space. The eye is a clear, calm region (light winds of no more than $15 \mathrm{mph}$ with no clouds) that

Table 2. The seven tropical cyclone seasons in the world.

\begin{tabular}{ccc}
\hline Season name & Starts & Ends \\
\hline Atlantic Hurricane Season & June 1 & November 30 \\
Eastern Pacific Hurricane Season & May 15 & November 30 \\
Northwest Pacific Typhoon Season & all year & all year \\
North Indian Cyclone Season & April 1 & December 31 \\
Southwest Indian Cyclone Season & October 15 & May 31 \\
Australian/Southeast Indian Cyclone Season & October 15 & May 31 \\
Australian/Southwest Pacific Cyclone Season & November 1 & April 30
\end{tabular}

Related references: Authors, adapted from various sources including the websites of the NOAA's Hurricane Research Centre (HRC) and National Weather Service (NWS), the UK Met Office. 


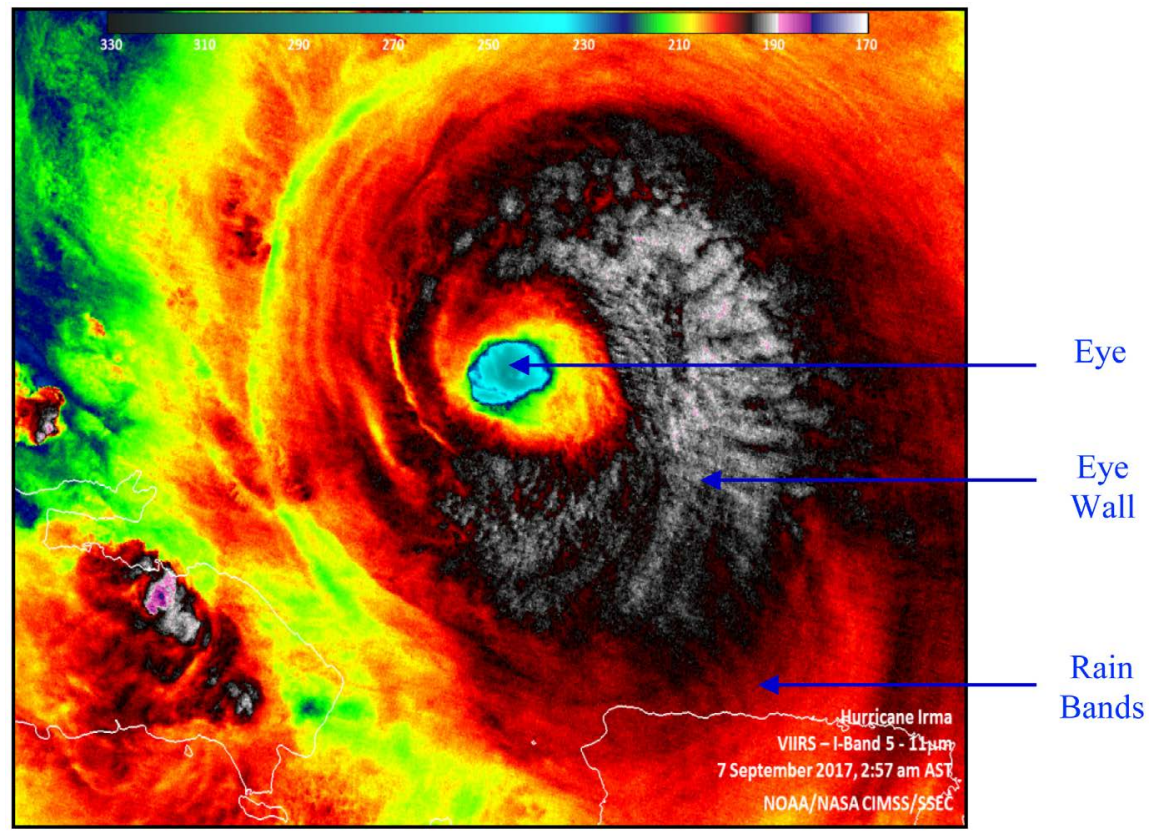

Figure 2. Satellite image of Hurricane Irma showing the eye of the storm. Related references: NOAA/NASA.

can extend to diameters of a hundred miles or more. Bordering the eye is the eye wall that consists of bands of clouds, very strong winds and heavy rainfall. Beyond the eye wall are feeder or rain bands, with intense thunderstorms, gusty winds, and often heavy rain showers that spiral inward toward the eye wall. Feeder bands can be very extensive, going outwards for many miles and they often cause tornadoes. The spiral shape or rotating vortex can have an average diameter of about $500 \mathrm{~km}$ and can extend to a height of about $15 \mathrm{~km}$. A fully formed TC may only cease after making landfall when the heat source is terminated or when the moisture content is cut off on land [16] [19] [20] [25] [30] [31] [32] [33].

\subsection{Categories of Tropical Storms}

Hurricanes are ranked into five different intensities based on their wind speed; strength and damage potential according to the Saffir-Simpson hurricane wind scale (Table 3). The ranks increase from one to five as the wind speed increases. Category 1 is the weakest, with wind speeds of $74-95 \mathrm{mph}$ while category five is the strongest and most dangerous with wind speeds exceeding $157 \mathrm{mph}$.

\subsection{Total Overall Hurricane Seasonal Activity}

Concise metrics have been developed to summarize a hurricane "seasonal activity ${ }^{38}$ indicating how busy or intense a hurricane season or regional storm activity has been. This is determined by calculating the season's accumulated cyclone

${ }^{8}$ The phrase total seasonal activity refers to the collective intensity and duration of Atlantic named storms and hurricanes occurring during a given season. 
Table 3. The five categories of severe storms.

\begin{tabular}{|c|c|c|c|c|c|}
\hline \multirow{2}{*}{ Category } & \multicolumn{3}{|c|}{ Sustained wind speed } & \multirow{2}{*}{$\begin{array}{c}\text { Storm surge } \\
(\mathrm{ft})\end{array}$} & \multirow{2}{*}{$\begin{array}{l}\text { Damage } \\
\text { potential }\end{array}$} \\
\hline & $\mathrm{mph}$ & $\mathrm{km} / \mathrm{h}$ & knots & & \\
\hline Tropical Depression & $<39$ & $<63$ & $<34$ & - & - \\
\hline Tropical Storm & $40-73$ & $64-117$ & $34-63$ & - & Very Minimal \\
\hline 1 & $74-95$ & $119-153$ & $64-82$ & $4-5$ & Minimal \\
\hline 2 & $96-110$ & $154-177$ & $83-95$ & $6-8$ & Moderate \\
\hline 3 & $111-129$ & $178-208$ & $96-112$ & $9-12$ & Major \\
\hline 4 & $130-156$ & $209-251$ & $113-136$ & $13-18$ & Extensive \\
\hline 5 & $\geq 157$ & $\geq 252$ & $\geq 137$ & $>18$ & Catastrophic \\
\hline
\end{tabular}

Related references: Authors, adapted from various sources including the websites of the NOAA's Hurricane Research Centre (HRC) and National Weather Service (NWS), the UK Met Office.

energy $(A C E)$ index $^{9}$ or Track Integrated Kinetic Energy (TIKE) metric ${ }^{10}[34]$ [35]. The ACE index of a season considers the number, frequency, strength or intensity and duration of all the tropical storms and hurricanes in the season. It is computed taking into account the lifetime of the storms and the maximum sustained wind speed [36]. The TIKE, however, is influenced by the size and strength of each storm, rather than solely focusing on maximum intensity without consideration for storm structure, as is the case with ACE [35].

The Climate Prediction Centre of the US government's National Atmospheric and Oceanic Administration (NOAA) classifies, or ranks, seasons based on the ACE index and the number of storms that have formed within a particular season as above normal, near normal, or below normal. An above-normal season is one that has an ACE index above $111 \times 104 \mathrm{kt}^{2}$ and at least two of the following conditions: 1) thirteen or more tropical storms, 2) seven or more hurricanes and 3) three or more major hurricanes. A near-normal season has an ACE index below $66 \times 104 \mathrm{kt}^{2}$ and the following three conditions: 1) nine or less tropical storms, 2) four or less hurricanes and 2) one or less major hurricanes. A season is called below normal when it has an ACE range of $66-111 \times 104 \mathrm{kt}^{2}$ and 1) four or less tropical storms and 2) two or less hurricanes. In particular, long-lived, intense hurricanes have a high ACE index, while short-lived, weak tropical storms have a low value [37]. Table 4 shows the ten extreme seasons from 1960-2017 based on their ACE index.

\subsection{Tropical Cyclone Season Forecasts}

Before the season starts, meteorologists forecast how active the upcoming season may be. Forecast agencies including governments, universities and private companies issue publicly available AHS predictions. The lead agencies in this field

${ }^{9}$ The ACE index is a wind energy index measured by convolving the AHS's intensity, duration and frequency every six hours for all named systems while they are at least tropical storm strength.

${ }^{10} \mathrm{TIKE}$ is calculated by accumulating the integrated kinetic energy of each tropical cyclone wind field in six-hour intervals throughout a hurricane season. 
Table 4. 10 extreme hurricane seasons based on the ACE from 1960 to 2016.

\begin{tabular}{cccccccc}
\hline Year & $\begin{array}{c}\text { Named } \\
\text { storm }\end{array}$ & $\begin{array}{c}\text { Named } \\
\text { storm days }\end{array}$ & Hurricanes & $\begin{array}{c}\text { Hurricane } \\
\text { days }\end{array}$ & $\begin{array}{c}\text { Major } \\
\text { hurricanes }\end{array}$ & $\begin{array}{c}\text { Major } \\
\text { hurricane } \\
\text { days }\end{array}$ & $\begin{array}{c}\text { Accumulated } \\
\text { cyclone energy } \\
\text { (ACE) }\end{array}$ \\
\hline 2005 & 28 & 131.5 & 15 & 49.75 & 7 & 17.5 & 250 \\
2004 & 15 & 93 & 9 & 45.5 & 6 & 22.25 & 227 \\
1995 & 19 & 121.25 & 11 & 61.5 & 5 & 11.5 & 227 \\
1998 & 14 & 88 & 10 & 48.5 & 3 & 9.5 & 182 \\
1999 & 12 & 78.5 & 8 & 41 & 5 & 14.25 & 177 \\
2003 & 16 & 81.5 & 7 & 32.75 & 3 & 16.75 & 176 \\
1969 & 18 & 92.25 & 12 & 40.25 & 5 & 6.5 & 166 \\
1996 & 13 & 79 & 9 & 45 & 6 & 13 & 166 \\
2010 & 19 & 89.5 & 11 & 38.5 & 12 & 5 & 165 \\
1980 & 11 & 62.25 & 9 & 38.25 & 2 & 7.25 & 149 \\
\hline
\end{tabular}

Related references: Authors, Adapted from [38].

are the NOAA agency, UK government's National Weather Service (Met Office), the Tropical Meteorology Project (TMP) at Colorado State University (CSU), North Carolina State University, University College London's (UCL) Tropical Storm Risk (TSR) Consortium and the Commercial forecaster AccuWeather.com (see Table 8). The pre-season outlooks and/or forecasts ${ }^{11}$ include guesstimates of the number of named storms, hurricanes, and major hurricanes. These are usually issued twice each year-April or May prior to the start of the season in June, and then an update in August [39].

Forecasting hurricanes have several limitations. It is based, for instance, on statistical schemes, which, owing to their intrinsically probabilistic nature, can fail in some years and forecasts do not predict with precision where the storms will strike within the Atlantic basin [40]. Moreover, forecasters caution that, within a single year, there is no solid relationship between the number of storms in a season and the number of landfalls because local weather conditions determine whether hurricanes will make landfall. For example, Hurricane Andrew (1992) occurred in one of the quietest AHS; yet at the time, it was the most expensive hurricane ever to hit the US. These shortcomings highlight the fact that despite huge efforts in prediction/forecasts, there has been little improvement in hurricane intensity forecasts since 1990 [41].

Regardless of the shortcomings in forecasting, an undisputable fact is that seasonal forecasts are good for hurricane risk reduction and management. Indeed, TC mortality and injury have been reduced by improved forecasts and preparedness, especially in developed countries [4]. People may sometimes base key decisions, such as to buy insurance on forecasts of an inactive season. How-

${ }^{11}$ Forecasts are based on the premise that past global oceanic and atmospheric conditions that preceded comparatively active or inactive hurricane seasons in the past provide meaningful information about similar trends in future seasons. 
ever, the danger is that seasonal forecast can by grossly misinterpreted making it counterproductive. This is because seasons with few hurricanes do not necessarily imply the hurricanes will not be very powerful. For example, as mentioned earlier, the relatively quiet 1992 season produced devastating hurricanes like Hurricane Andrew [41].

\section{Method}

This article adopts a qualitative, analytic approach. The objective is to explore the 2017 AHS to understand how it was different from other seasons. Qualitative research is appropriate for investigating the "who, what, and where" of events or experiences and for gaining insights regarding a poorly understood phenomenon [42]. The techniques used are based mainly upon secondary and primary information sources. Secondary sources of information include peer review articles, reports from government, private and local weather/climate monitoring and prediction/forecasting agencies. In particular, key primary information sources (various types of analytical, cause/effect, interpretive, argumentative and forecast papers and reports) about the 2017 AHS were obtained from the websites of the US NOAA's National Weather Service (NWS) and National Hurricane Centre (NHC) and the UK's Meteorological Office (UK Met Office). Other reports and statements made by prominent meteorologists, weather forecasters and climatologists about the 2017 AHS from varied sources also constitute primary source of information. In addition, grey literature from media/newspaper sources about the 2017 AHS and other reports from internet searches also informed the research. Indeed, due to unprecedented innovations in scientific monitoring and measurements of hurricane activity, meteorological data, substantiated by the analysis of meteorologists/climatologists and the effects of the storms was available even as the season unfolded. Multiple techniques were used to analyze data, including content analysis, descriptive statistics and constant comparison and sequential description of events [42] [43] [44] [45].

\section{Result and Discussion}

This section analysis how the 2017 AHS is distinct from other seasons in terms of the characteristics of the storms that formed, their impact, effects or losses caused, why the season was very active and its forecast.

\subsection{The Storms of the 2017 Atlantic Hurricane Season}

The NOAA, UK Met Office and forecast agencies track, monitor and document all the storms that develop every year. In 2017, the Atlantic region was hit by a frenetic stretch of long-lived tropical monster storms, many of them major and dramatic. The 2017 AHS produced 17 storms. Ten were hurricanes (six category 3 or stronger) and the other seven were tropical storms. The season started on April 19 with tropical storm Arlene and extended to November 9, lasting 7 months (Figure 3). The maximum wind speed recorded was $185 \mathrm{mph}$ (295 $\mathrm{km} / \mathrm{h}$ ) by Hurricane Irma. 


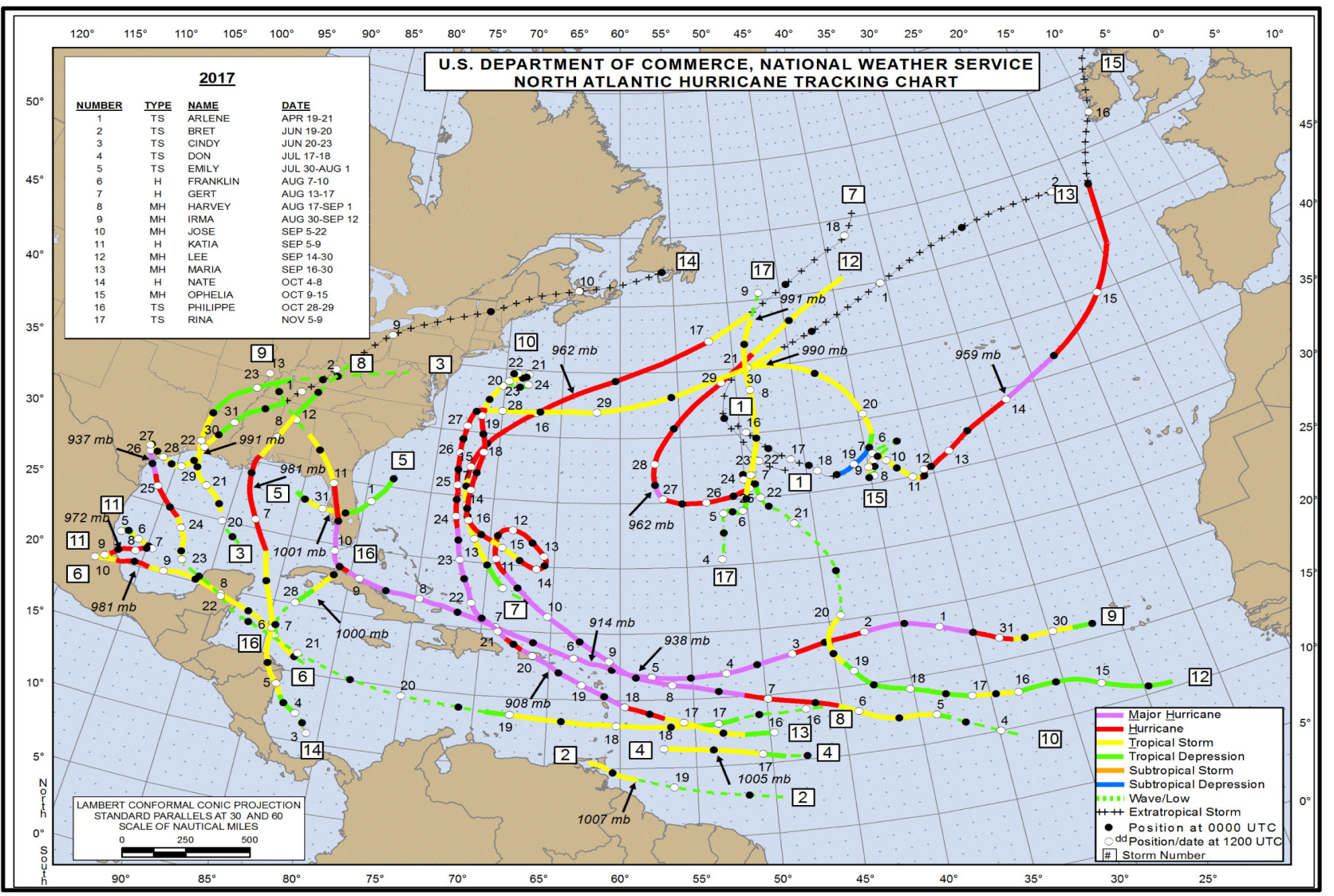

Figure 3. 2017 Atlantic Tropical Cyclone tracks. Related references: NOAA’s NHC website.

A prominent caveat of the 2017 AHS is the occurrence of several storms and back-to-back hurricanes (Table 5) in a season classified as above average (see Section 2.7).

The first hurricane of the season was "Franklin" that developed into a hurricane on August 8 and made landfall in Lechuguillas (Mexico). It quickly dissipated into a tropical storm two days later. On August 13, storm "Gert" intensified to a Category 1 hurricane but just 12 hours after achieving peak intensity, the storm weakened below hurricane status. While Gert was dissipating, Hurricane Harvey was brewing in the Caribbean and attained hurricane status on August 24. After leaving a trail of destruction in the Caribbean and South East USA, Harvey spun down into a tropical storm on the August 26. Barely 7 days after Harvey's onslaught, Hurricane Irma came into line and developed into Category 5 intensity. Irma ravaged several Caribbean islands and barreled directly into Florida before losing its hurricane character. Irma was downgraded into a tropical storm on September 11.

While Irma was still battering the US, storm Jose attained hurricane intensity on September 6 in the Atlantic Ocean and peaked to Category 4 hurricane on September 9. After leaving a lasting impact in the Caribbean islands, Jose stalled offshore into the North East USA on September 22 as a post-tropical cyclone [46]. On September 6, in the Gulf of Mexico, storm Katia also became a hurricane 
Table 5. Storms that formed in the 2017 North Atlantic hurricane season.

\begin{tabular}{|c|c|c|c|}
\hline Name of storm & Active storm dates & Max wind speed Mph $(\mathrm{km} / \mathrm{h})$ & Category at peak intensity \\
\hline Arlene & 19-21 Apil & $50(80)$ & TS \\
\hline Bret & 19-20 Jun & $45(72)$ & TS \\
\hline Cindy & 20-23 Jun & $60(97)$ & TS \\
\hline Don & 17-1 Jul & $50(85)$ & TS \\
\hline Emily & 31 July-2 Aug & $45(80)$ & TS \\
\hline Franklin & 8-10 Aug & 85 (138) & H Cat 1 \\
\hline Gert & 13-17 Aug & $105(170)$ & H Cat 2 \\
\hline Harvey & 17 Aug-1 Sep & $130(209)$ & H Cat 4 \\
\hline Irma & 30 Aug-12 Sep & $185(298)$ & H Cat 5 \\
\hline Jose & 5-22 Sep & $155(249)$ & H Cat 4 \\
\hline Katia & 5-9 Sep & $105(169)$ & H Cat 2 \\
\hline Lee & 15-30 Sept & $115(185)$ & H Cat 3 \\
\hline Maria & 16-30 Sep & $175(282)$ & H Cat 5 \\
\hline Nate & 4-9 Oct & 90 (149) & H Cat 1 \\
\hline Ophelia & $9-15 \mathrm{Oct}$ & $115(185)$ & H Cat 3 \\
\hline Philippe & $28-29$ Oct & $60(95)$ & TS \\
\hline Rina & 5-9 Nov. & $60(95)$ & TS \\
\hline \multicolumn{4}{|c|}{ Total for Season } \\
\hline 17 & April 19-Nov. 9 & $1540(2496)$ & \\
\hline
\end{tabular}

Related references: Authors, compiled from various sources including the websites of the NOAA's NHC/NWS, UK Met Office; Caribbean Weather/Weather.org.

but peaked only at Category 2. After making landfall in Tecolutla (Mexico) as a Category 2 hurricane, the system quickly dissipated on September 9. While Irma was still active, storm Maria developed into a hurricane on September 16 and quickly attained Category 5 status on September 18. After devastating the Eastern Caribbean Islands and some areas of South East USA, Maria transitioned into a tropical cyclone on September 30. "Nate" developed into TS from the SW Caribbean Sea on October 5. After making landfall in the US on October 8 as Category 1 hurricane, it quickly dissipated into a tropical depression the next day. Storm Ophelia attained hurricane status on October 11. It dissipated into a tropical storm on October 16 shortly before making landfall in the British Isles-although still alive even at this stage with gusts in excess of $90 \mathrm{mph}$ that devastated parts of Northern Ireland (causing three fatalities).

\subsection{How the 2017 Atlantic Hurricane Season Is Unique}

Table 6 is a summary of the unique characteristics of the 2017 AHS, including new meteorological records set when compared to other seasons.

The 2017 AHS is compelling and stands out as one of the most notorious 
Table 6. Unique characteristics of the 2017 AHS.

\begin{tabular}{|c|c|}
\hline Criteria & Characteristic of the 2017 Atlantic Hurricane Season \\
\hline $\begin{array}{l}\text { All-Time } \\
\text { Record }\end{array}$ & $\begin{array}{l}\text { - The ACE units produced by the Atlantic basin storms in September (155.4, surpassed that of } \\
\text { - September } 2004 \text { to become the most active calendar month in the Atlantic on record. } \\
\text { More ACE was generated on September } 8,2017 \text { than any other calendar day in the Atlantic basin on record, } \\
\text { - Fintly contributed by Hurricanes Jose, Irma and Katia. } \\
\text { continental USA in a single year. } \\
\text { - Ophelia was the easternmost major hurricane in the Atlantic basin on record that underwent extratropical } \\
\text { transition as it impacted the United Kingdom and Ireland in mid-October. } \\
\text { - Tropical Storm Bret was the earliest named storm to form in the main development region }{ }^{12} \text { on record, } \\
\text { surpassing the record of Tropical Storm Ana in } 1979 \text {. } \\
\text { - Harvey was the most enduring tropical storm on record after making landfall as a hurricane in } \\
\text { Texas staying at tropical storm strength or greater for } 117 \text { hrs. } \\
\text { - Harvey was the wettest tropical cyclone in the US history, dropping } 34 \text { trillion gallons of water across East Texas } \\
\text { and Western Louisiana and almost } 52 \text { inches of rain in six days } \\
\text { - Harvey produced } 51.8 \text { inches of rain at Cedar Bayou, Texas-the most ever recorded in US mainland } \\
\text { from a tropical cyclone. } \\
\text { - Hurricane Harvey was the first storm to make two landfalls in the Gulf of Mexico more than } 60 \text { hours apart. } \\
\text { - Irma was the strongest Atlantic storm in Caribbean Sea on record. } \\
\text { - Irma stayed as a Category } 5 \text { hurricane in the Atlantic for the longest time ( } 78 \text { hours) } \\
\text { - Irma is the only tropical storm to have sustained very intensive wind speeds at } 185 \text { mph ( } 298 \mathrm{~km} / \mathrm{h} \text { ) for about } 37 \text { hours. } \\
\text { - Hurricane Nate's forward speed of } 28 \text { mph ( } 45 \mathrm{~km} / \mathrm{hr} \text { ) was the fastest recorded motion of a hurricane } \\
\text { in the Gulf of Mexico. } \\
\text { - Hurricane Irma was the closest approach of a Category } 5 \text { hurricane to the Turks and Caicos Islands }\end{array}$ \\
\hline $\begin{array}{l}\text { Compared to } \\
\text { Other Seasons }\end{array}$ & 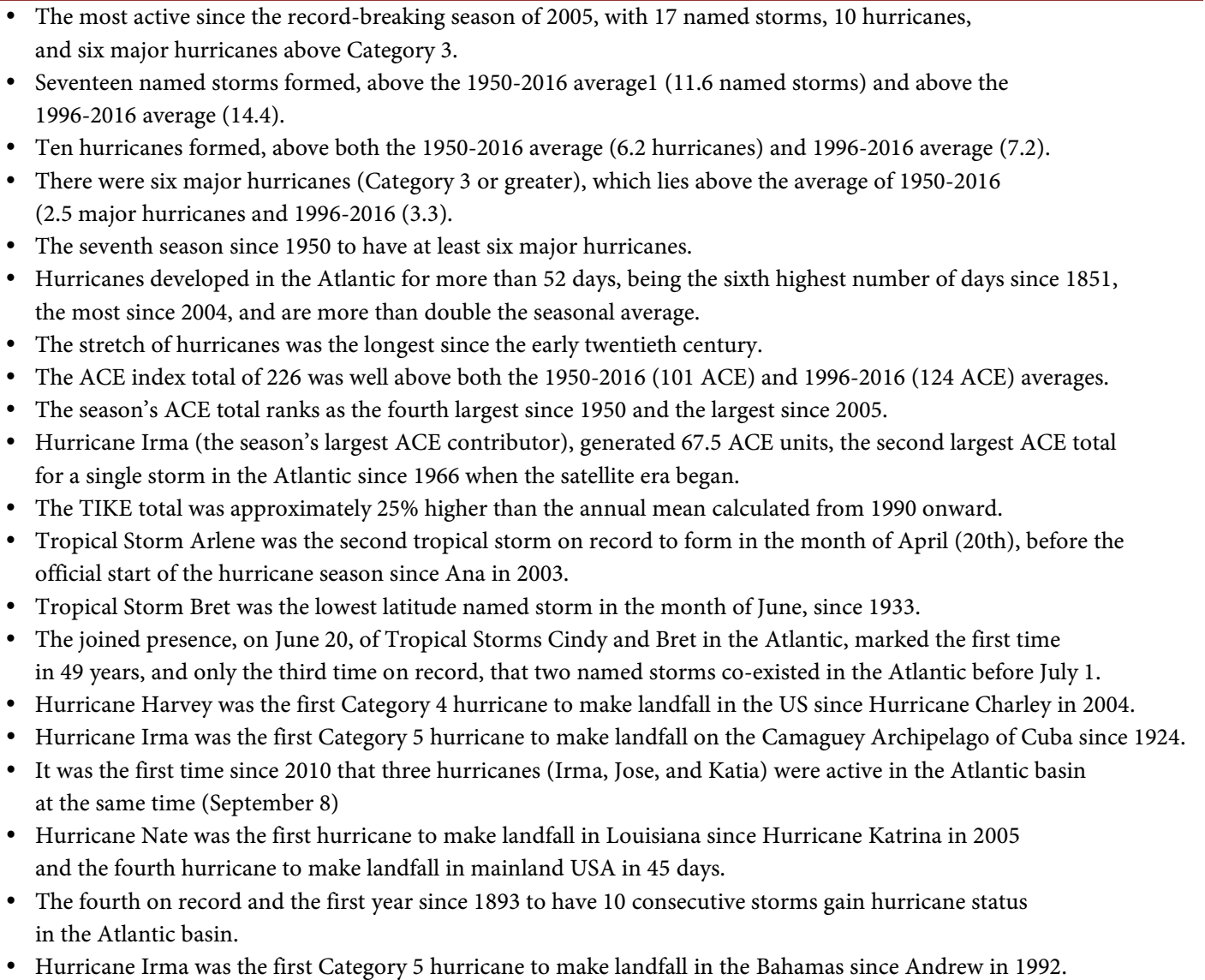 \\
\hline
\end{tabular}

Related references: Authors, compiled from various sources including NOAA's NWS, UK Met Office [19] [47] [48] [49].

${ }^{12}$ The main development region spans the tropical Atlantic Ocean and the Caribbean Sea between $10^{\circ} \mathrm{N}-20^{\circ} \mathrm{N}, 20^{\circ} \mathrm{W}-80^{\circ} \mathrm{W}$. 
when compared to other hurricane seasons. Many new hurricane records were set. Since the development of the satellite for observing hurricane formation in the early 1960s, 2017 is the only year where there have been ten consecutive hurricanes in the Atlantic basin. The 2017 AHS is the most active since the record-breaking season of 2005 and is now ranked amongst the top ten most active seasons since records began. Compared to historical database for land falling hurricanes (Figure 4), the 17 storms that formed in 2017 is above the 1950-2016 average $^{13}$ (11.6) and the 1996-2016 average (14.4). The number of hurricanes (10) is above both the 1950-2016 average (6.2 hurricanes) and 1996-2016 average (7.2). The major hurricanes of the season (6) surpass the average of 1950-2016 (2.5) and 1996-2016 (3.3).

Philippe Klotzbach ${ }^{14}$ tweeted that there were "only eight other years, dating to the mid-1 $9^{\text {th }}$ century that had generated seven or more hurricanes by September 17". Indeed, it was the first time two Category 4 hurricanes (or stronger) had made landfall in the USA from the Atlantic Ocean since weather records began in 1851. It is rare for a Category 4 (or stronger) Atlantic hurricane to reach the US. Only 29 hurricanes (including Harvey, Irma, Jose and Maria that formed in 2017) have been documented since 1851; of which four were Category 5 hurricanes. Since Hurricane Charley devastated South West Florida in 2004, Harvey's strike on Texas was the first to occur in the US and landfalls of that strength have not happened since Hurricane Andrew (Category 5) devastated South Florida in 1992. In the Caribbean, the situation is similar. Harvey was the first Category

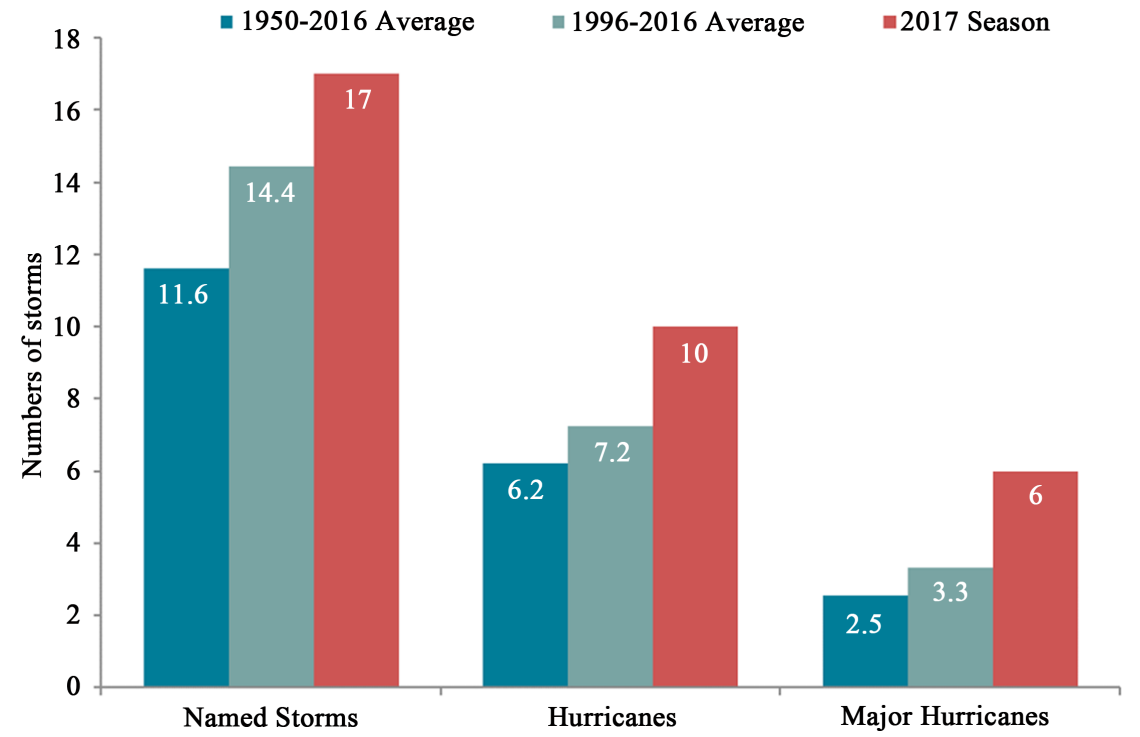

Figure 4. Comparison of the 2017 AHS storms to that between 1950-2016 and 1996-2016 averages. Related references [47].

\footnotetext{
${ }^{13}$ Although the historical database for hurricanes that make landfall worldwide is complete from 1900, the record of hurricane activity in the Atlantic Basin is complete only from 1950 onward due to the start of satellite technology and aircraft reconnaissance.

${ }^{14}$ Philippe Klotzbach is a Meteorologist with Colorado State University and expert in both hurricane seasonal forecasting and hurricane climatology.
} 
5 hurricane to hit Dominica and Puerto Rico since at least 1851 and 1928 respectively.

During 2017, hurricanes developed in the Atlantic for more than 52 days. That is the sixth highest number of days since 1851, the most since 2004, and is more than double the seasonal average. Eminent meteorologists Bob Hansen ${ }^{15}$ described the season: "This season has been an overachiever by almost every index... we are running at about twice the pace of a typical season". Eric Blake ${ }^{16}$, a scientist at the NOAA similarly remarked: "Never seen anything like this in the modern record".

In addition, it is notable that during the 2017 AHS six major hurricanes (>Category 3) passed through the Atlantic hurricane basin. It is rare for two hurricanes to pass through the same region in the same year. The last time this happened was in 1829 when the northern Leeward Islands were hit by two major hurricanes in the same season. Maria (Category 4) was the strongest storm to have hit Puerto Rico in 85 years. The 30-year average number of hurricanes for an entire AHS is six. Yet by mid-October 2017, 10 hurricanes had been recorded in the Atlantic.

The first major hurricane of the season, Harvey (Category 4) was the 18th strongest hurricane to make landfall in the US since 1851 and ninth strongest to hit Texas. Harvey has gone down on record as the wettest tropical cyclone in the US history, dropping 34 trillion gallons of water across East Texas and western Louisiana and almost 52 inches of rain in six days [49]. The storm produced 51.8 inches of rain at Cedar Bayou, Texas-the most ever recorded in US mainland from a tropical cyclone, breaking the previous record of 48 inches set in Texas by Tropical Storm Claudette in 1979. Philippe Klotzbach tweeted that, "Harvey broke the longest-running US land falling major hurricane drought at 4,323 days".

Irma was the 11th most intense hurricane on record in the Atlantic basin, the strongest Atlantic storm in Caribbean Sea on record and the only Category 5 storm to have made direct impact in the northern Leeward Islands [46] [50]. Hurricane Irma's peak wind speed of $185 \mathrm{mph}$ is the second highest ${ }^{7}$ on record, only surpassed by Hurricane Allen (1980) which reached wind speeds of 190 $\mathrm{mph}$. Moreover, Irma is on record as the only tropical storm worldwide to have sustained very intensive wind speeds at $185 \mathrm{mph}(298 \mathrm{~km} / \mathrm{h})$ for about 37 hours, beating the previous record for a storm of that intensity held by Typhoon Haiyan, which was at maximum intensity for 24 hours. Furthermore, Irma remained a Category 5 Hurricane for the longest time since satellite storm tracking began (at 3.25 days), tied only with the 1932 Cuba Hurricane and the first Category 5 Hurricane to have hit Cuba since 1924 [50].

\footnotetext{
${ }^{15}$ Bob Hansen is Weather Underground's senior meteorologist, co-editor of Category 6, and author of "Meteorology Today" and "The Thinking Person's Guide to Climate Change."

${ }^{16}$ Eric Blake is a hurricane specialist at NOAA's National Hurricane Center in Miami, Florida.

${ }^{17}$ Irma's speed is tied with hurricanes Gilbert (1988), Wilma (2005) and the Florida Keys hurricane of 1935.
} 
Moving north-westward at $28 \mathrm{mph}(44 \mathrm{~km} / \mathrm{h})$, Hurricane Nate was the fastest-moving storm ever recorded in the Gulf of Mexico, according to the National Weather Service. In addition, Nate was the first tropical cyclone to move ashore in the state of Mississippi since Hurricane Katrina (Washington Post, edition of October 8, 2017). Hurricane Ophelia was the easternmost Atlantic major hurricane on record and the worst storm on record to hit N Ireland with gusts of 90 mph that caused three fatalities [45] [51].

Also remarkable during the 2017 AHS is the stretch of hurricanes. This was the longest since the early twentieth century (Figure 5). The timeline for each hurricane to form-one after the other, was very short, averaging only about 6 days between Hurricanes Franklin, Gert and Harvey. Indeed, for three weeks in September 2017, five hurricanes occurred concurrently in the NE Atlantic. These hurricanes were also, notably, long-lived. Included in this series was Harvey (15 days), followed by Irma (14 days) then by longest lived Jose (18 days) and the next longest-lived Maria (15 days) and then Nate (6 days).

The 2017 AHS had an ACE index of 226 that is above the 1950-2016 (101 ACE) average and ranked the fourth largest since 1950 (Figure 6). Only three other seasons (1995, 2004 and 2005) have had a higher ACE since 1960 (Table 4).

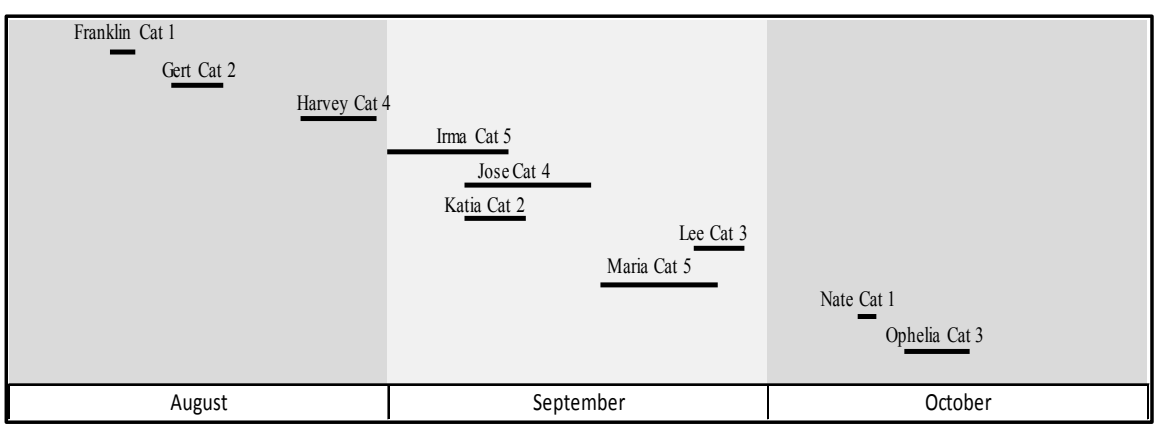

Figure 5. Timeline for hurricanes that formed in the 2017 Atlantic Season. Related references: Authors.

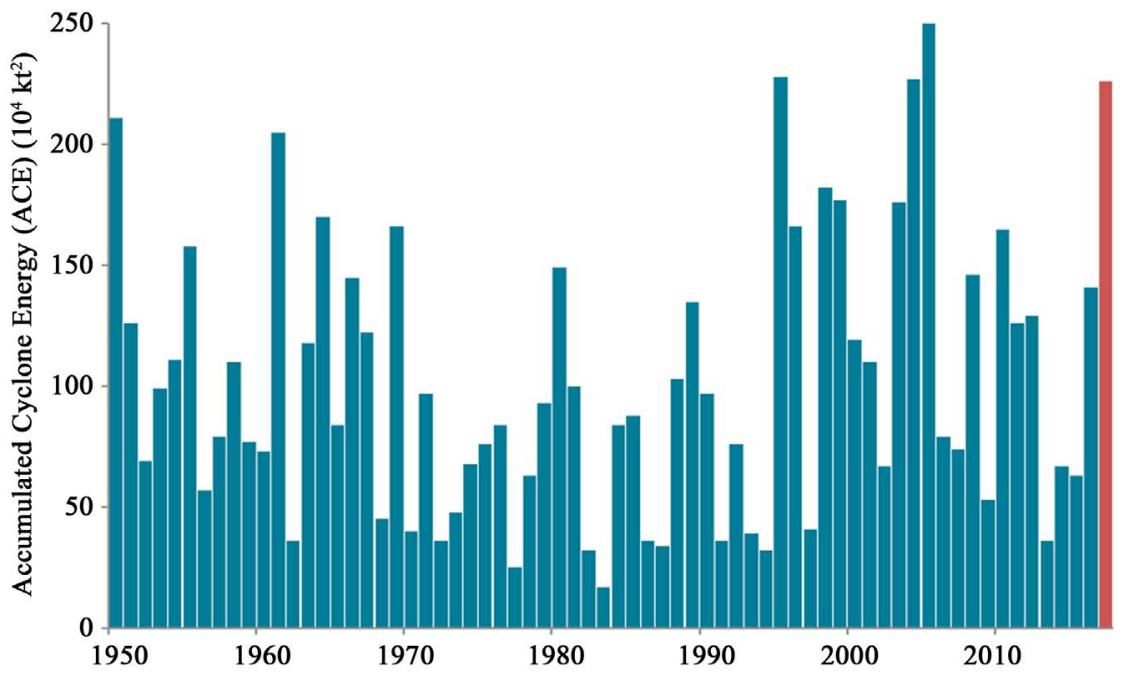

Figure 6. Atlantic Hurricane Season ACE totals from 1950-2017. Related references [47]. 
Irma, Jose and Maria, long-lived hurricanes with strong, wide wind fields, were the greatest contributors to the season's total ACE and TIKE. Irma generated more ACE than any Atlantic tropical cyclone on record and accrued the third-highest ACE index on record by mid-September although roughly 38\% of an average AHS's ACE index occurs after September 18. The TIKE total for the 2017 AHS (10,500 TJs) was about 25\% higher than the annual mean from 1990-2016 [46] [47] [50].

\subsection{Losses Incurred during the 2017 Atlantic Hurricane Season}

The 2017 AHS is the most expensive on record, culminating in more than $\$ 202.6$ billion in damage [52] [53]. The havoc caused was immense. Table 7 shows the storms that caused considerable damage during the 2017 AHS, and their estimated financial and human costs.

Whilst the full economic impact of the 2017 hurricanes continues to be assessed, preliminary analysis indicates large gross losses from affected short-term investment flows and lost value of capital stock (damages to roads, infrastructure, housing, commercial property, agricultural). Arguably, 2017 is one of the most expensive seasons on record including in the USA especially when compared to Hurricane Katrina and other major hurricanes in 2005 that caused about $\$ 143.5$ billion in damage.

In the USA, Harvey caused damages of $\$ 126$ billion, mainly in Texas. Indeed, Harvey and Irma have joined the list of "billion-dollar hurricanes", the latter being the fifth most expensive hurricane to hit the US [11]. The secondary effects to the US economy could be dire. For instance, it was estimated that Harvey could have reduced Texas's GDP growth to $2.7 \%$ from $4.3 \%$ in 2017 , while Irma also reduced Florida's real GDP growth from 3.6\% down to $2.5 \%$ in 2017. According to the US Energy Information Administration, Hurricane Harvey caused the US refining capacity to drop from $97 \%$ on August $25 \%$ to $78 \%$ on September 8 and this caused retail gasoline prices to increase by 32 cents $(13.2 \%)$ between August 21 and September 11 [49] [54].

Notwithstanding the relative size of the US economy, the much smaller economies of the Caribbean nations were seriously affected. Prior to 2017, the largest hurricane cost in the Caribbean was caused by Hurricane George (1998), which ravaged six islands causing almost US\$11 billion in damages [10]. In 2017, however, the cost was far higher. Irma and Maria caused losses worth $\$ 51$ billion and $\$ 91$ billion respectively in Puerto Rico [11]. Irma's damages amounted to $\$ 1.5$ billion for Saint Martin, $\$ 500$ million for the Turks and Caicos Islands, $\$ 480$ million for St. Bathelemy, \$150 - 300 million for Barbuda, \$190 million for Anguilla, and $\$ 200$ million (uninsured losses) for Cuba [50]. Indeed, such economic losses have the potential to set back development in the Caribbean for several decades. The Washington Post (edition of September 15, 2017) reported the Antigua and Barbuda's ambassador to the USA describing the damage: "For the first time in 300 years there's not a single living person on the island of Barbuda-a civilization that has existed on that island for over 300 years has now been 
Table 7. Storms and associated hazards and their effects during the 2017 AHS.

\begin{tabular}{|c|c|c|c|c|c|}
\hline $\begin{array}{l}\text { Storm } \\
\text { name }\end{array}$ & Locations affected & Associated hazards & Effect & $\begin{array}{l}\text { Damage } \\
\text { (USD) }\end{array}$ & Deaths \\
\hline Bret & $\begin{array}{l}\text { Trinidad, Tobago } \\
\text { Venezuela, Guyana, } \\
\text { Windward Islands }\end{array}$ & $\begin{array}{l}\text { Strong winds, } \\
\text { Heavy rainfall. } \\
\text { Mudslides, Flooding. }\end{array}$ & $\begin{array}{l}\text { Hundreds of houses } \\
\text { damaged and flooded }\end{array}$ & $\begin{array}{l}\geq \$ 3.3 \\
\text { million }\end{array}$ & 1 \\
\hline Cindy & $\begin{array}{l}\text { Mississippi, Louisiana, Honduras, } \\
\text { Belize, Cayman Islands, Peninsula, } \\
\text { Cuba, Southern } \\
\text { Eastern USA Yucatán }\end{array}$ & $\begin{array}{l}\text { Heavy rainfall } \\
\text { Storm surge. } \\
\text { Strong winds \& } \\
\text { Flash flooding. }\end{array}$ & $\begin{array}{l}\text { Minor flooding in rivers, } \\
\text { tidal flooding. } \\
\text { Power outages, } \\
\text { damage to property. }\end{array}$ & $\begin{array}{l}\simeq \$ 26 \\
\text { million }\end{array}$ & 1 \\
\hline Don & $\begin{array}{l}\text { Trinidad and Tobago, } \\
\text { Port of Spain, } \\
\text { Windward Island, Barbados }\end{array}$ & $\begin{array}{l}\text { Heavy rainfall, } \\
\text { Thunderstorms, } \\
\text { Localized flash flooding. }\end{array}$ & $\begin{array}{l}\text { Houses inundated \& } \\
\text { property damaged }\end{array}$ & NA & None \\
\hline Emily & $\begin{array}{c}\text { Florida } \\
\text { (Collier \& Miami-Dade } \\
\text { Counties, Miami Beach, Bradenton) }\end{array}$ & $\begin{array}{l}\text { Wind gusts, } \\
\text { thunderstorms, } \\
\text { high tides }\end{array}$ & $\begin{array}{l}\text { Damages to homes, } \\
\text { localized power outages } \\
\text { \& flooding. }\end{array}$ & $\begin{array}{l}\simeq \$ 11 \\
\text { million }\end{array}$ & None \\
\hline Franklin & $\begin{array}{l}\text { Veracruz, Guatemala, Honduras, } \\
\text { Yucatan Peninsula, Central Mexico }\end{array}$ & $\begin{array}{c}\text { Strong winds, heavy rains, } \\
\text { flooding, landslides and } \\
\text { mudslides }\end{array}$ & $\begin{array}{l}\text { Dozens of homed damaged, } \\
\text { power outages affected } \\
\text { over } 300,000 \text { people, homes } \\
\text { inundated by flood waters. }\end{array}$ & $\begin{array}{l}\simeq \$ 15 \\
\text { million }\end{array}$ & None \\
\hline Harvey & $\begin{array}{c}\text { NE and SE USA } \\
\text { (Florida, Georgia, Texas) } \\
\text { Leeward Hispaniola, Islands, } \\
\text { Cape Verde, Puerto Rico, Turks and } \\
\text { Caicos Islands, The Bahamas, Cuba, }\end{array}$ & $\begin{array}{l}\text { Strong winds. } \\
\text { Record breaking rainfall, } \\
\text { Storm surge, tides, } \\
\text { intense flash flooding. }\end{array}$ & $\begin{array}{c}\text { More than } 300,000 \text { structures } \\
\text { and 500,000 cars were } \\
\text { damaged, over } \\
110,000 \text { structures flooded. }\end{array}$ & $\begin{array}{l}\simeq \approx 126 \\
\text { billion }\end{array}$ & 68 \\
\hline Irma & $\begin{array}{l}\text { Saint-Martin, Anguilla, Tortola, St. } \\
\text { Thomas and St. John, Puerto Rico, } \\
\text { Dominican Republic, Haiti, } \\
\text { South Caicos, Hispaniola, Turks, } \\
\text { The Bahamas, Cuba, SE United States } \\
\text { (Florida and Georgia), NE United States }\end{array}$ & $\begin{array}{l}\text { Strong hurricane category } \\
\text { winds, heavy rains, } \\
\text { storm surge, flood. }\end{array}$ & $\begin{array}{l}\text { About } 1100 \text { buildings damaged } \\
\text { or destroyed, water supply } \\
\text { system damaged, } \\
\text { Airport severely } \\
\text { damaged, power \& } \\
\text { telecommunication affected }\end{array}$ & $\begin{array}{l}\simeq \$ 64.76 \\
\text { billion }\end{array}$ & 52 \\
\hline Jose & Leeward Islands, Barbuda, East USA & $\begin{array}{l}\text { Strong winds, } \\
\text { heavy rainfall. }\end{array}$ & $\begin{array}{l}\text { Hampered humanitarian } \\
\text { and relief assistance }\end{array}$ & $\begin{array}{l}\simeq \$ 2.5 \\
\text { million }\end{array}$ & 1 \\
\hline Katia & East Mexico & $\begin{array}{l}\text { Heavy rainfall, } \\
\text { mudslides, landslips }\end{array}$ & $\begin{array}{l}53 \text { Municipalities reported } \\
\text { damages to infrastructures. }\end{array}$ & NA & None \\
\hline Maria & $\begin{array}{l}\text { Lesser Antilles, Palmas Del Mar, } \\
\text { Guayama, Rio Grande, Arecibo, } \\
\text { Puerto Rico, San Juan. Hispaniola, } \\
\text { Turks and Caicos Islands, } \\
\text { Bahamas, SE USA. }\end{array}$ & $\begin{array}{l}\text { Intense rainfall and winds, } \\
\text { flash and river flooding. }\end{array}$ & $\begin{array}{l}=90 \% \text { of buildings in Dominica } \\
\text { destroyed, Electricity \& } \\
\text { water supply affected, } \\
\text { Communications systems } \\
\text { downed, Plantations damaged } \\
\text { in Guadeloupe. Disruption } \\
\text { of normal operations, weather } \\
\text { radar destroyed Roads and } \\
\text { bridges damaged, Partial } \\
\text { failure of Guajajara Dam. }\end{array}$ & $\begin{array}{c}\simeq \$ 92 \\
\text { billion }\end{array}$ & 148 \\
\hline Nate & $\begin{array}{l}\text { Honduras, Nicaragua, Panama, } \\
\text { Costa Rica, Mexico, Cuba, } \\
\text { Cayman Islands, SE \& NE USA }\end{array}$ & $\begin{array}{l}\text { Heavy rainfall, } \\
\text { River \& storm surge } \\
\text { flooding, landslides }\end{array}$ & $\begin{array}{c}\text { Extensive } \\
\text { property/infrastructure } \\
\text { damage, Downed trees } \\
\text { and electricity poles }\end{array}$ & $\begin{array}{l}\simeq \approx 787 \\
\text { million }\end{array}$ & 46 \\
\hline Ophelia & UK, Ireland & Strong winds & $\begin{array}{l}\text { Affected power lines \& caused } \\
\text { minor damage to property } \\
\text { and downed trees. }\end{array}$ & $\begin{array}{c}>\$ 14 \\
\text { million }\end{array}$ & 3 \\
\hline
\end{tabular}




\section{Continued}

\begin{tabular}{|c|c|c|c|c|c|}
\hline Philippe & $\begin{array}{c}\text { Florida, N. Carolina. Cuba, } \\
\text { Cayman Islands, } \\
\text { Yucatán Peninsula, }\end{array}$ & $\begin{array}{l}\text { Gale-force winds, } \\
\text { tornadoes, } \\
\text { localized flooding. }\end{array}$ & Minimal damage to houses & NA & None \\
\hline
\end{tabular}

Related references: Authors, compiled from various sources including [11], [46] [47] NOAA's NHC/NWS, UK Met Office.

extinguished". He said reconstruction could cost up to USD \$300 million.

The impact on the population and to the environment was considerable. Irma caused untold sufferings in the Caribbean. Puerto Rico experienced island-wide power outages due to extensive damages on the energy grid. More than one million people were left without power and 6,000 others sort refuge in shelters. In Tortola, St. Thomas, St. John, Dominican Republic and Barbuda, Irma's severe wind and storm surge caused substantial structural damages to hundreds of buildings and the communication systems. Prime Minister Gaston Browne of Antigua and Barbuda claimed that the Islands were barely habitable afterwards, with $95 \%$ if the buildings destroyed. The international NGO, Oxfam, estimated that more than 24,000 people were displaced in the Dominican Republic and more than 5,000 people were evacuated. In Haiti, the storm caused flooding and mudslides that damaged hundreds of homes. In the USA, Irma's landfall was associated with riverine flooding that reached up to 1.8 meters in several locations in Florida, causing significant damage.

Maria caused substantial structural and roof damage to buildings in St. Croix and Palmas Del Mar, Guayama, Rio Grande, Fajardo, Caguas and Arecibo. Low lying areas at St. Thomas suffered flooding damage. Trees in the region were stripped of their leaves and Guadeloupe's banana plantations were severely damaged. In Puerto Rico, Maria exacerbated the power outages caused by Irma, causing significant damage to several large wind turbines and damaged weather radars on the Island. The storm also caused 70,000 people to be evacuated in northern Puerto Rico due to the danger of dam failure [47] [48] [49] [55].

The insurance industry also suffered huge losses from the major hurricanes. Estimates indicate insured losses from $\$ 25$ to $\$ 40$ billion for Harvey, $\$ 35$ to $\$ 55$ billion for Irma, $\$ 15$ to $\$ 30$ billion and $\$ 15$ to $\$ 30$ billion for Maria. These estimates represent insured loss associated with storm surge, coastal and inland flood and wind damage in the US and the Caribbean. Implications to the banking industry include higher delinquency rates and deterioration in the quality of collaterals in affected areas [47] [56].

The ramifications of the losses are even dire when the knock-on effects to the economies of the Caribbean countries are considered! These include a short-term curtailment of economic activity resulting from a reduction in trade and investment, income, consumption and value of services. These could seriously affect the national economies of the countries impacted in the long-term.

\subsection{Why Was the 2017 Atlantic Season So Active?}

The severity of the storms reignited discussions and arguments that seek to ex- 
plain why the 2017 AHS season was so active. At the center of these discussions is whether global warming and/or Climate Change (CC) are playing a significant role. Many scientists argue, and we agree, that this seems to be the case, evidenced by the increasing number and intensity of the storms.

Scientists have established that ocean temperatures in the Atlantic have been increasing steadily over the last few decades due to CC, and this is fueling the frequency, intensity and tracks of TCs [3] [15]. For instance, they argue that global warming is contributing to an increase in water vapor in the atmosphere. Indeed since 1988, the amount of total water vapor column over the global oceans has increased by $1.3 \%$ per decade [57]. This is causing an increase in the rainfall potential with the prediction that this will lead to an increased ferocity of TCs in the second half of the 21st Century [3]. In fact, climate predictions based on global warming suggest that average-intensity TCs will likely get even more intense in the coming decades as the earth continues to warm ${ }^{18}$ [15]. Actually, a 0.5 centigrade increase in sea surface temperature (SST) can lead to a $40 \%$ increase in hurricane activity [58].

The 2017 AHS was definitely characterized by highly favorable environmental oceanic and atmospheric conditions that favored cyclogenesis (see Section 2.5) and promoted the above-average hurricane activity (see Section 2.7). During the first half of 2017, the central equatorial Pacific Ocean warmed to borderline El Niño ${ }^{19}$ conditions. At the start of the 2017 AHS, tropical Pacific Ocean SSTs and upper ocean heat content cooled rapidly, and El Niño-Southern Oscillation $(\mathrm{ENSO})^{20}$, which significantly influence inter-annual hurricane activity, quickly transitioned toward La Niña conditions by mid-summer ${ }^{21}$. The lack of El Niño, therefore, leads to a reduction in mid-troposphere vertical wind shear in the Western Pacific Ocean in 2017 [15] [46]. This was highlighted by an atmospheric scientist at Massachusetts Institute of Technology, Kerry Emanuel, who remarked? "El Niño is stuck in neutral this year...there's currently little difference in wind speeds near the surface and those roughly 10 miles up, which ensures that miles-tall hurricanes can form and remain stable". Atlantic hurricanes are suppressed when an El Niño is underway in the Pacific because its shearing winds ${ }^{22}$ can dissipate nascent storms [21] [29].

In August 2017, the NOAA explained that unseasonably warm ocean temper-

\footnotetext{
${ }^{18}$ Both higher standard surface temperatures and increased water vapor tend to increase the energy available for atmospheric convection, such as thunderstorms, and for the development of tropical cyclones.

${ }^{19} \mathrm{El}$ Niño is the warming of sea surface temperature that occurs every few years, typically concentrated in the central-east equatorial Pacific with a global impact including increasing wind shear across the tropical Atlantic.

${ }^{20} \mathrm{ENSO}$ is a coupled ocean-atmosphere climate fluctuation over the tropical Pacific that transitions between warmer (El Niño) and cooler (La Niña) phases, typically over a two- to seven-year period. ${ }^{21}$ Sea surface temperature declines of this magnitude (around $1^{\circ} \mathrm{C}\left(1.8^{\circ} \mathrm{F}\right)$ in the four months between April and August are highly unusual and normally only occur following strong winter El Niño events.

${ }^{22}$ This is the difference between the winds in the upper troposphere and those at the ocean surface, has been very weak over the tropical North Atlantic.
} 
atures and the lack of El Niño would cause the busiest season in seven years. And this was the case in the main Atlantic basin where SSTs increased considerably $^{23}$ (Figure $7(a)$ ), reaching their warmest since 2010 . The high temperatures caused instability in the atmosphere, which led to the low-level convergence of moisture, winds, and latent heat creating very favorable conditions for systems to develop rapidly and sustain strong intensities for long periods of time. The warmer oceans arguably made Irma and Harvey far more destructive than they would have been in previous decades. Meteorologist Sean Sublette ${ }^{24}$ stated that: "CC makes these bad storms worse... CC can make it totally disastrous or catastrophic". If global temperatures continue to rise, it is estimated that the average annual hurricane damages in the Caribbean will increase between

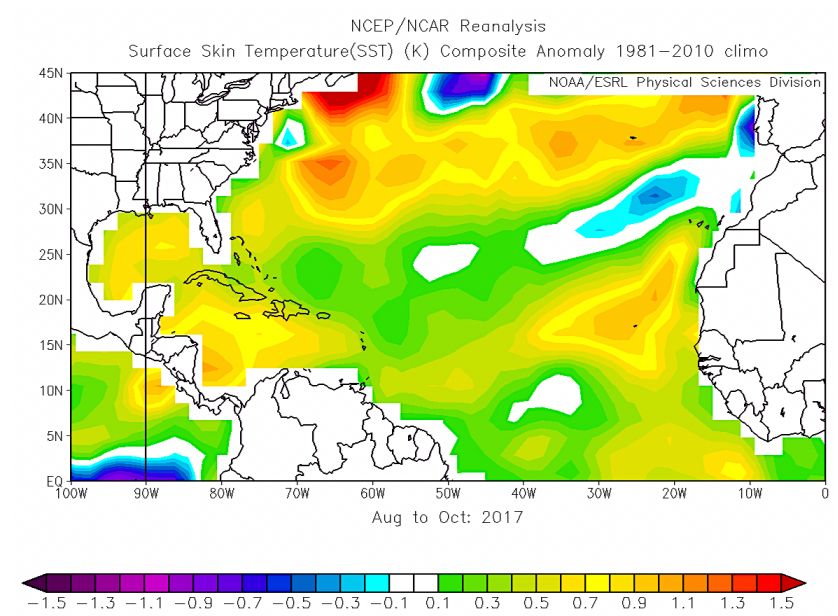

(a)

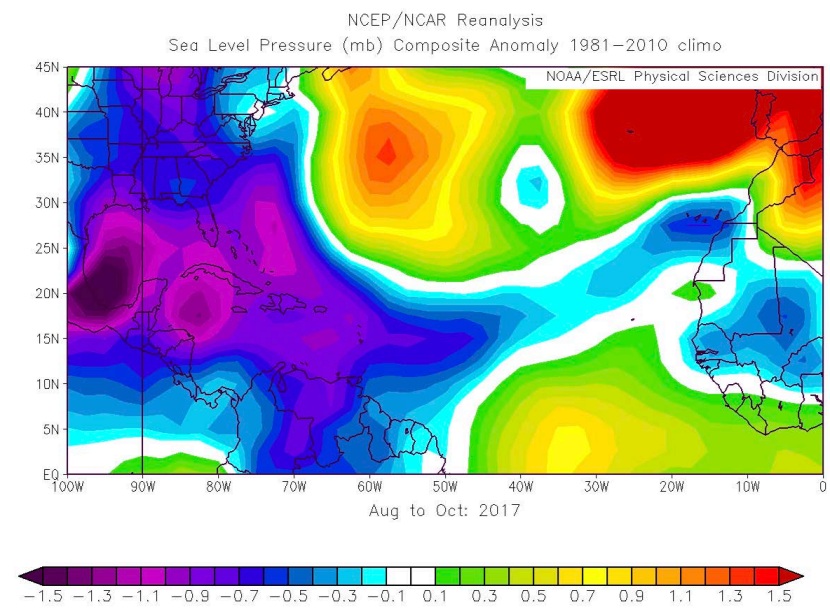

(c)

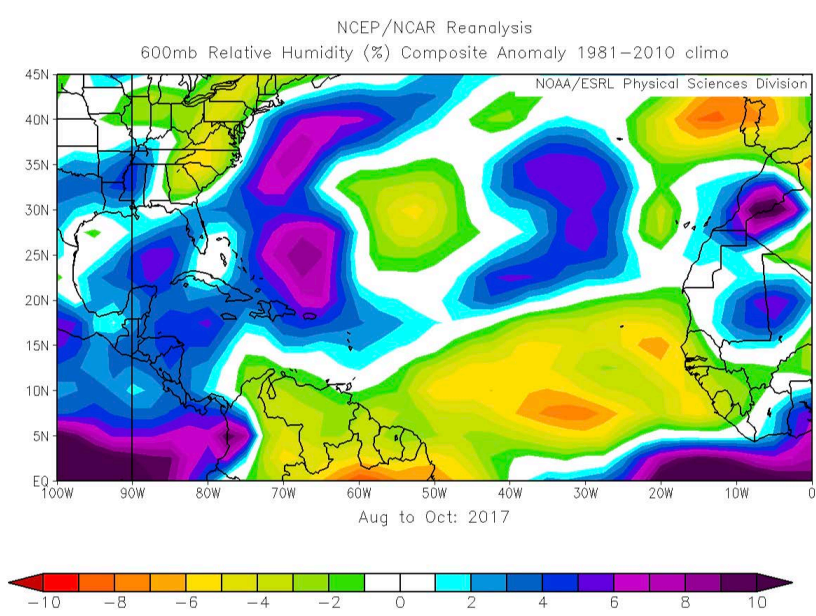

(b)

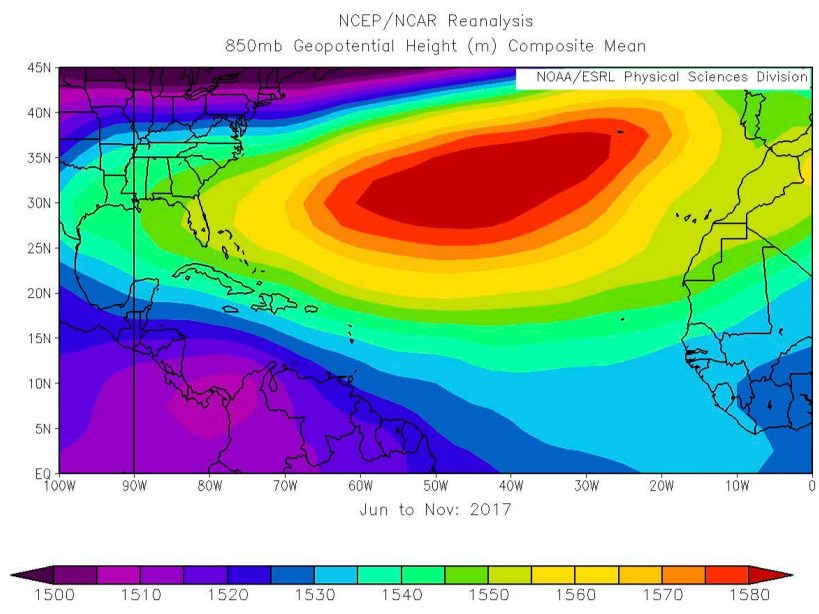

(d)

Figure 7. (a) 2017 AHS Sea surface temperature anomalies ( $\left.{ }^{\circ} \mathrm{K}\right)$ from August to October; (b) 600 mb relative humidity (\%) moisture anomalies for the period through August to October; (c) Sea surface pressure (mb) anomalies from August to October; (d) $850 \mathrm{mb}$ Geopotential Height $(\mathrm{m})$ composite mean for the period June to November 2017. Related references: NOAA/ESRL PSD.

\footnotetext{
${ }^{23}$ The sea surface temperatures in September were the third warmest temperature on record.

${ }^{24}$ Sean Sublette is a meteorologist with Climate Central, a non-profit group that studies climate change.
} 
$22 \%$ and $77 \%$ by the year 2100 [10].

The entire Atlantic basin (Gulf of Mexico, Caribbean Sea and Western Atlantic) experienced above-average moisture content (Figure 7(b)) especially in September (the peak months of the season) that produced the major hurricanes. As mentioned in Section 2.2, a higher concentration of water vapor in the atmosphere fuels storm development and intensification [59] [60] especially if there is no dust blowing across the Atlantic from Africa, which tends to have a drying effect on developing storms [28] [61]. In fact, the Climate Prediction Centre asset that in 2017, a strong West African monsoon aligned to make the Caribbean Sea and part of the tropical Atlantic particularly well suited to hurricanes. Furthermore, the sea level pressure across the Atlantic basin in 2017 was generally below average (Figure $7(\mathrm{c})$ ); thereby enhancing cyclone activity. Furthermore, a proper steering pattern was in place-the Atlantic subtropical high extended much further west than in previous decades, creating a predominantly steering flow towards land (Figure $7(\mathrm{~d})$ ). This position, therefore, directed the major storms on a westward trajectory towards the Caribbean Sea and South East USA [45] [46]. These hurricane-friendly environmental and atmospheric conditions in 2017 arguably contributed not only to more, but stronger, hurricanes in 2017.

\subsection{Atlantic Hurricane Season Forecast}

The pre-2017 season forecast did not reflect what actually transpired. Indeed, there was no indication of the hyperactivity of the season that involved the major hurricanes and associated ACE index observed. Rather, most pre-season forecasts issued between April and June indicated a slightly below-average to above-average activity.

The TMP's pre-season forecasts in April 2017 predicted a slightly below-average activity for the 2017 Atlantic basin hurricanes [48]. In fact, the CSU also made an early forecast that the season would be about $30 \%$ below both the 1950-2016 long-term norms and the recent 2006-2015 10-year norm [58]. Prior to the official start of the hurricane on June 1, the main forecast agencies (CSU and TSR) [38], predicted an average to slightly above-average activity (Table 8). In May 2017, the NOAA said the season had a $45 \%$ chance of an above average season ${ }^{25}$. In August, the NOAA upgraded their forecast that: "the season has the potential to be extremely active and could be the most active since 2010". Accordingly, the TMP and TSR later updated their forecasts to indicate a busier season (above average). The agencies attributed the hyperactivity of the 2017 AHS to environmental anomalies in the central Atlantic. However, the disparities in the earlier forecasts show that it is impossible to precisely predict a season's hurricane activity in early April (see Section 2.7) [39].

${ }^{25}$ The NOAA predicted that there is a $70 \%$ chance of having 11 to 17 named storms, of which five to nine could develop into hurricanes, including two to four major hurricanes (categories 3-5). 
Table 8. June 2017 Seasonal forecasts for North Atlantic Hurricane Season with the final numbers for the 2017 season.

\begin{tabular}{ccccc}
\hline Forecast group & $\begin{array}{c}\text { Tropical } \\
\text { storms }\end{array}$ & Hurricanes & $\begin{array}{c}\text { Major } \\
\text { hurricanes }\end{array}$ & $\begin{array}{c}\text { ACE Index } \\
\left(104 \mathrm{kt}^{2}\right)\end{array}$ \\
\hline NOAA CPC15 (May 25) & $11-17$ & $5-9$ & $2-4$ & - \\
CSU16 (June 1) & $14(10-18)$ & $6(4-8)$ & $2(1-3)$ & $100(52-148)$ \\
TSR (May 26) & $14( \pm 4)$ & $6( \pm 3)$ & $3( \pm 2)$ & $98( \pm 48)$ \\
U.K. Met Office17 (June 1) & $13(10-16) 18$ & $8(6-10)$ & - & $145(92-198)$ \\
N. Carolina State University (April 18) & $11-15$ & $4-6$ & $1-3$ & - \\
Penn State University (April 25) & $15(11-20)$ & - & - & - \\
AccuWeather (May 31) & 10 & 5 & 3 & - \\
The Weather Company (May 20) & 14 & 7 & 3 & - \\
Weather Tiger (April) & 14 & 7 & $2-3$ & 110 \\
Weather BELL Analytics (May 12) & $11-13$ & $4-6$ & $1-2$ & $75-95$ \\
All Forecast Groups & $10-17$ & $4-9$ & $1-4$ & $75-145$ \\
2017 Season & $(10-20)$ & $(3-10)$ & $(1-5)$ & $(50-198)$ \\
\hline
\end{tabular}

Related references: [46].

\section{Conclusions and Recommendations}

The 2017 AHS is arguably one of the worst seasons in years by various meteorological standards. The season will be remembered for its many storms, the number of these storms that became hurricanes, their intensity and ferocity, and the manner by which so many storms passed through the same path at the same time.

Key characteristics also make the 2017 AHS distinct from others. The season recorded 10 hurricanes cumulatively for 52 days, with six major ones (>Category 3); the September ACE index (155.4) makes it the most active Atlantic calendar month on record; it was the first time two Category 4 or stronger Atlantic hurricanes reach the US and the stretch of hurricanes that formed was the longest in the 20th and 21st century. The season recorded the most enduring wettest hurricane to hit the USA; Irma was the strongest Atlantic storm in the Caribbean Sea ever and was a Category 5 hurricane for the longest time since records began. In terms of cost, the season is the most expensive on record ( $>202.6$ billion economic cost) with potentially dire ramifications to the small Caribbean economies in the long-term.

There is general consensus amongst scientists that the unusually high meteorological activities of the 2017 AHS were due to anomalous high hurricane friendly environmental conditions - such as, the lack of ENSO and reduction in mid-troposphere vertical wind shear, considerable increase in SSTs, above-average moisture content and below-average sea level pressures. They also advance scientific evidence to support the thesis that the magnitude of Harvey, Irma, 
Maria and other recent storms highlights the effects of global warming and indicative of CC.

Interestingly, early forecasts predicted a rather calm season, contrary to what was experienced, which highlights limitations in forecasting these forces of nature. Yet, early predictions are important because they allow enough time to prepare for hurricane impact. With predictions that the incidence of storms will intensify and increase substantially by the end of this century and as rapid intensification is difficult to forecast [15], there is a risk of an increased frequency of poorly anticipated, high-intensity hurricanes making landfalls with potentially dire ramifications. These challenges call for the urgency to take action at every level of society to minimize the impact of an ever-increasing number and severity of severe storms as those experienced during the 2017 AHS.

Therefore, countries prone to TCs will be served well by focusing on ways to recognize and internalize the costs of these storms and to prepare for the predicted intensification of TCs due to CC. Consequently, appreciable decreases in vulnerability to these storms-for example, through land use policies, building codes or better preparedness, and evacuation procedures or better forecasting-could reduce TC-related casualties.

In this light, this paper advances for a more proactive approach in dealing with these severe storms. Effective mitigation of TC impacts and its effects on society will require a strategic move from a reactionary to an anticipatory policy. This will entail devising a well-designed and comprehensive emergency management system that focuses on effective disaster management evacuation plans, reducing the vulnerabilities of "at-risk" populations and enhancing capabilities. From a disaster management perspective, irrespective of how active a season might be, vulnerable communities should always heed to advice and directions from disaster/emergency management agencies. The 2017 AHS is a clear reminder for the world to always expect the unexpected in natural phenomenon, and for the emergency, disaster management and forecasting services to always strive for continual improvements in their anticipatory and preparatory strategies.

\section{Conflicts of Interest}

The authors declare no conflicts of interest regarding the publication of this paper.

\section{References}

[1] Young, R., Zieger, S. and Babanin, A. (2011) Global Trends in Wind Speed and Wave Height. Science, 332, 451-455. https://doi.org/10.1126/science.1197219

[2] Kerry, E. (2005) Increasing Destructiveness of Tropical Cyclones over the Past 30 Years. Nature, 436, 686-688. https://doi.org/10.1038/nature03906

[3] IPCC (2014) Climate Change 2014: Synthesis Report. Contribution of Working Groups I, II and III to the Fifth Assessment Report of the Intergovernmental Panel on Climate Change. Geneva.

[4] Peduzzi, P., Chatenoux, B., Dao, H., De Bono, A., Herold, C., Kossin, J., Mouton, F. 
and Nordbeck, O. (2012) Global Trends in Tropical Cyclone Risk. Nature, 2, 289-294. https://doi.org/10.1038/nclimate1410

[5] Zandbergen, P. (2009) Exposure of US Counties to Atlantic Tropical Storms and Hurricanes, 1851-2003. Natural Hazards, 48, 83-99.

https://doi.org/10.1007/s11069-008-9250-6

[6] Lopez-Marrero, T. and Wisner, B. (2012) Not in the Same Boat: Disasters and Differential Vulnerability in the Insular Caribbean. Caribbean Studies, 40, 129-168. https://doi.org/10.1353/crb.2012.0034

[7] McEntire, D. (2012) Emergency Management in the United States: Disasters Experienced, Lessons Learned, and Recommendations for the Future. In: McEntire, A., Ed., Comparative Emergency Management: Understanding Disaster Policies, Organizations, and Initiatives from Around the World, FEMA, Washington DC. https://training.fema.gov/hiedu/aemrc/booksdownload/compemmgmtbookproject/

[8] NOAA/HRD (2018) Chronological List of All Hurricanes Which Affected the Continental United States 1851-2016. http://www.aoml.noaa.gov/hrd/tcfaq/E23.html

[9] Acevedo, S. (2016) Gone with the Wind: Estimating Hurricane Climate Change Costs in the Caribbean. IMF Working Paper WP/16/199. https://doi.org/10.5089/9781475544763.001

[10] NOAA/NCEI (2018) Billion-Dollar Weather and Climate Disasters: Overview. https://www.ncdc.noaa.gov/billions

[11] Bueno, R., Herzfeld, C., Stanton, E. and Ackerman, F. (2008) The Caribbean Climate Change: The Cost of Inaction.

http://ase.tufts.edu/gdae/pubs/rp/caribbean-full-eng.pdf

[12] IMF (2013) Caribbean Small States: Challenges of High Debt and Low Growth. https://www.imf.org/external/np/pp/eng/2013/022013b.pdf https://doi.org/10.5089/9781498342261.007

[13] NCA (2014) Climate Change Impacts in the United States, US Global Change Research Program. http://s3.amaznaws.com/nca2014/low/NCA3_Highlights_LowRes.pdf?download=1

[14] Kerry, E. (2017) Will Global Warming Make Hurricane Forecasting More Difficult? Bulletin of American Meteorological Society, 98, 495-501. https://doi.org/10.1175/BAMS-D-16-0134.1

[15] Kerry, E. (2005) Divine Wind: The History and Science of Hurricanes. Oxford University Press, New York.

[16] Nelson, S. (2014) Tropical Cyclones (Hurricanes). http://www.tulane.edu/ sanelson/New_Orleans_and_Hurricanes/tropical_cyclones. $\underline{\mathrm{htm}}$

[17] WMO (2016) Regional Association I-Tropical Cyclone Operational Plan for the South.

[18] UKMetOffice (2018) Tropical Cyclone Facts. https://www.metoffice.gov.uk/research/weather/tropical-cyclones/facts

[19] NOAA (2018) What Is the Difference between a Hurricane and a Typhoon? https://oceanservice.noaa.gov/facts/cyclone.html

[20] Henderson-Sellers, A., Zhang, G., Bertz, G., Emmanuel, K., Gray, W., Landsea, C., Holland, G., Lighthill, J., Shieh, S., Webster, P. and McGuffie, K. (1998) Tropical Cyclone and Global Climate Change: A Post-IPCC Assessment. Bulletin of American Meteorological Society, 79, 1649-1668.

https://doi.org/10.1175/1520-0477(1998)079<0019:TCAGCC $>2.0 . C O ; 2$ 
[21] Hart, R. (2006) Hurricanes: A Primer on Formation, Structure, Intensity Change and Frequency. http://icecap.us/images/uploads/409.pdf

[22] Kerry, E. (2007) Environmental Factors Affecting Tropical Cyclone Power Dissipation. Journal of Climate, 20, 5497-5509. https://doi.org/10.1175/2007JCLI1571.1

[23] Mark, S. and Lea, A. (2008) Large Contribution of Sea Surface Warming to Recent increase in Atlantic Hurricane Activity. Nature, 451, 557-561. https://doi.org/10.1038/nature06422

[24] NASA (2018) How Do Hurricanes Form? https://spaceplace.nasa.gov/hurricanes/en

[25] Abbott, P.L. (1996) Natural Disasters. Wm. C. Brown Publishing Co., New York.

[26] Murck, B., Brian, J. and Stephen, C. (1997) Dangerous Earth, an Introduction to Geologic Hazards. John Wiley and Sons, New York.

[27] Hopsch, S.B., Thorncroft, C.D., Hodges, K. and Aiyyer, A. (2007) West African Storm Tracks and their Relationship to Atlantic Tropical Cyclones. Journal of Climate, 20, 2468-2483. https://doi.org/10.1175/JCLI4139.1

[28] Aiyyer, A. and Thorncroft, C. (2006) Climatology of Vertical Shear over the Tropical Atlantic. Journal of Climate, 19, 2969-2983. https://doi.org/10.1175/JCLI3685.1

[29] Pearce, R. (2005) Why Must Hurricanes Have Eyes? Weather, 60, 19-24. https://doi.org/10.1256/wea.50.04

[30] Sriver, L. and Huber, M. (2007) Observational Evidence for an Ocean Heat Pump Induced by Tropical Cyclones. Nature, 447, 577-580.

https://doi.org/10.1038/nature05785

[31] Knutson, T., McBride, J., Chan, J., Kerry, E., Greg, H., Chris, L., Held, I., Kossin, P., Srivastava, A. and Sugi, M. (2010) Tropical Cyclones and Climate Change. Nature Geoscience, 3, 157-163. https://doi.org/10.1038/ngeo779

[32] Mei, W., Primeau, F., McWillams, J. and Pasquero, C. (2013) Sea Surface Height Evidence for Long-Term Warming Effects of Tropical Cyclones on the Ocean. Proceedings of the National Academy of Sciences, 110, 15207-15210. https://doi.org/10.1073/pnas.1306753110

[33] Bell, G. and Chelliah, M. (2006) Leading Tropical Modes Associated with Inter-Annual and Multi-Decadal Fluctuations in North Atlantic Hurricane Activity. Journal of Climate, 19, 590-612. https://doi.org/10.1175/JCLI3659.1

[34] Misra, V., Dinapoli, S. and Powell, M. (2013) The Track Integrated Kinetic Energy of Atlantic Tropical Cyclones. Monthly Weather Review, 141, 2383-2389. https://doi.org/10.1175/MWR-D-12-00349.1

[35] Powell, M. and Reinhold, T. (2007) Tropical Cyclone Destructive Potential by Integrated 627 Kinetic Energy. Bulletin of American Meteorological Society, 88, 513-526. https://doi.org/10.1175/BAMS-88-4-513

[36] Villarini, G. and Vecchi, G. (2012) North Atlantic Power Dissipation Index (PDI) and Accumulated Cyclone Energy (ACE): Statistical Modeling and Sensitivity to Sea Surface Temperature Changes. Bulletin of American Meteorological Society, 25, 625-637. https://doi.org/10.1175/JCLI-D-11-00146.1

[37] Levinson, D. (2005) State of the Climate 2004. American Meteorological Society, Boston, 1-86. https://doi.org/10.1175/BAMS-86-6-Levinson

[38] CSU TMP (2018) North Atlantic Ocean Historical Tropical Cyclone Statistics. http://tropical.atmos.colostate.edu/Realtime/index.php?arch\&loc=northatlantic

[39] NOAA/CPC (2018) NOAA 2018 Atlantic Hurricane Season Outlook. http://www.cpc.ncep.noaa.gov/products/outlooks/hurricane.shtml 
[40] Klotzbach, P. and Bell, M. (2017) Extended Range Forecast of Atlantic Seasonal Hurricane Activity and Landfall Strike Probability for 2017. http://webcms.colostate.edu/tropical/media/sites/111/2017/04/2017-04.pdf

[41] DeMaria, M., Sampson, C., Knaff, J. and Musgrave, K. (2014) Is Tropical Cyclone Intensity Guidance Improving? Bulletin of American Meteorological Society, 95, 387-398. https://doi.org/10.1175/BAMS-D-12-00240.1

[42] Bhattacherjee, A. (2012) Social Science Research: Principles, Methods, and Practices. 2nd Edition, CreateSpace Independent Publishing Platform, Tampa.

[43] Neergaard, M., Olesen, F., Andersen, S. and Sondergaard, J. (2009) Qualitative Description-The Poor Cousin of Health Research? BMC Medical Research Methodology, 9, 52-57. https://doi.org/10.1186/1471-2288-9-52

[44] Vaismoradi, M., Turunen, H. and Bondas, T. (2013) Content Analysis and Thematic Analysis: Implications for Conducting a Qualitative Descriptive Study. Nursing and Health Sciences, 15, 398-405. https://doi.org/10.1111/nhs.12048

[45] Neuman, W. and Robson, K. (2015) Basics of Social Research: Qualitative and Quantitative Approaches. 3rd Canadian Edition, Pearson Canada, Toronto.

[46] NOAA/NHC (2017) Atlantic Tropical Cyclones and Disturbances. https://www.nhc.noaa.gov

[47] RMS (2018) 2017 North Atlantic Hurricane Season Review. http://forms2.rms.com/rs/729-DJX-565/images/NAHU2017-SeasonReview.pdf

[48] Brown, J. (2017) Hurricane Irma: The Damage to the Caribbean So Far. Financial Times (Edition of September 8, 2017). https://www.ft.com/content/507f0752-946d-11e7-bdfa-eda243196c2c

[49] Karp, N., Nava, M., Nash-Stacey, B. and Blazheski, F. (2017) Economic Impact of Hurricanes Harvey and Irma.

https://www.bbvaresearch.com/wpcontent/uloads/2017/09/170918_EconomicImpac t_Harvey_Irma-1.pdf

[50] Klotzbach, P. (2017) Hurricane Irma Meteorological Records Facts Recap Report. https://webcms.colostate.edu/tropical/media/sites/111/2017/09/Hurricane-Irma-Rec ords.pdf

[51] UK Met Office (2017) Ex-Hurricane Ophelia 16 October 2017. http://www.metoffice.gov.uk/weather

[52] Bacopoulos, P. (2018) Extreme Low and High Waters Due to a Large and Powerful Tropical Cyclone: Hurricane Irma (2017). Natural Hazards, 98, 939-968. https://doi.org/10.1007/s11069-018-3327-7

[53] Sullivan, B. (2017) The Most Expensive U.S. Hurricane Season Ever: By the Numbers.

https://www.bloomberg.com/news/articles/2017-11-26/the-most-expensive-u-s-hur ricane-season-ever-by-the-numbers

[54] Smith, A. and Matthews, J. (2015) Quantifying Uncertainty and Variable Sensitivity within the U.S. Billion-Dollar Weather and Climate Disaster Cost Estimates. Natural Hazards, 77, 1829-1851. https://doi.org/10.1007/s11069-015-1678-x

[55] OXFAM (2017) Hurricane Irma: Oxfam Assists Those Hit Hardest by Disasters-The Poorest People.

https://www.oxfam.org/en/pressroom/pressreleases/2017-09-12/hurricane-irma-oxf am-assists-those-hit-hardest-disasters-poorest

[56] LLOYDS (2018) After the Storms, Harvey, Irma and Maria: Lessons Learned. https://www.lloyds.com/news-and-risk-insight/risk-reports/library/natural-environ 
ment/afterthestorms

[57] Trenberth, K. (2005) Uncertainties in Hurricanes and Global Warming. Science, 308, 1753-1754. https://doi.org/10.1126/science.1112551

[58] Saunders, M. and Lea, A. (2017) April Forecast Update for Atlantic Hurricane Activity in 2017.

http://www.tropicalstormrisk.com/docs/TSRATLForecastApr2017.pdf

[59] Holland, G. (1997) The Maximum Potential Intensity of Tropical Cyclones. Journal of Atmosphere Sciences, 54, 2519-254.

https://doi.org/10.1175/1520-0469(1997)054<2519:TMPIOT>2.0.CO;2

[60] Beitler, J. (2019) Saharan Dust versus Atlantic Hurricanes. https://cdn.earthdata.nasa.gov/conduit/upload/1181/NASA_SOP_2007_Saharan_du st_versus_Atlantic_hurricanes.pdf

[61] Than, K. (2006) African Dust Storms Stifle Hurricanes, Study Suggests.

https://www.livescience.com/1080-african-dust-storms-stifle-hurricanes-study-sugg ests.html 